\title{
The role of lignin in wood working processes using elevated temperatures: an abbreviated literature survey
}

\author{
Zoltán Börcsök ${ }^{1} \cdot$ Zoltán Pásztory $^{1}$ (D)
}

Received: 30 March 2020 / Accepted: 17 November 2020 / Published online: 4 December 2020

(c) The Author(s) 2020

\begin{abstract}
The lignin, cellulose and hemicelluloses in wood are polymers that behave similarly to the artificial polymers and are bonded together in wood. Lignin differs from the other two substances by its highly branched, amorphous, three-dimensional structure. Under appropriate conditions, the moist lignin incorporated in the wood softens at about $100{ }^{\circ} \mathrm{C}$ and allows the molecules of it to deform in the cell walls. There are many advantages and disadvantages to this phenomenon. If we know this process accurately and the industrial areas where it matters, we may be able to improve these industrial processes. This article provides a brief theoretical summary of lignin softening and the woodworking processes where it plays a role: wood welding, pellet manufacturing, manufacturing binderless boards, solid wood bending, veneer manufacturing, and solid wood surface densification.
\end{abstract}

\section{Introduction: thermoplastic behavior of lignin}

Wood is actually a mixture of polymers, composed of partially crystalline cellulose microfibrils and large amorphous hemicellulose and lignin molecules. In lignin, phenyl propane units create chains, which are crosslinked in an amorphous, three-dimensional structure, linked to the cellulose fibrils via hemicelluloses (Sakakibara 1991; Zandersons et al. 2004; Rowell et al. 2005). Lignin can be classified based on the chemical structure of its monomer units. Three major groups can be distinguished: grass lignin, softwood lignin and hardwood lignin. Depending on the configuration of guaiacyl (G), syringyl (S) and p-hydroxyphenylpropane (H) units, grass lignin is classified as a GSH lignin, softwood lignin is classified as G lignin and GS in case of hardwoods (Sarkanen 1975; Stelte et al. 2011b; Sakakibara 1991). The amount of lignin varies between species, and also between individual tissues such as bark, earlywood, latewood, normal wood and compressed wood, branch wood, wood from the roots; also by cell types (parenchyma or fibers), and cell wall layers, for example middle lamella, primary and secondary wall layer, and cell corners. Lignin and its chemical

Zoltán Pásztory

pasztory.zoltan@uni-sopron.hu

1 University of Sopron, 4 Bajcsy-Zsilinszky E Str., Sopron 9400, Hungary composition can be examined by various techniques, such as ultraviolet microscopy (Lange 1954; Scott et al. 1969; Adler 1977; Fergus and Goring 1970a, b) densitometric analysis (Scott et al. 1969), interference microscopy (Donaldson 1985), SEM-EDXA (Westermark et al. 1988), transmissionelectron-microscopy (Fromm et al. 2003), and by confocal Raman microscopy (Gierlinger and Schwanninger 2006). The greatest concentrations of lignin were found in the compound middle lamella and in the cell corners; lower concentrations were found in the secondary cell walls (Fergus et al. 1969; Scott et al. 1969; Fergus and Goring 1970a; Donaldson 1985; Saka and Goring 1985; Westermark et al. 1988; Fromm et al. 2003; Gierlinger and Schwanninger 2006). Although the lignin concentration in the middle lamella and in the cell corners is high, these regions have a lower tissue volume than the secondary cell wall layers, so these regions accommodate only about one quarter of the total amount of lignin; indeed, most of the lignin is located in the secondary walls (Fergus and Goring 1970a, b; Adler 1977; Saka and Goring 1985). The lignin concentration of the vessel wall is higher than that of the fiber, while ray parenchyma cells have a lower lignin concentration than the fibers (Saka and Goring 1985).

A polymer can be amorphous or partially crystalline, determined primarily by the chemical structure of the polymer. If the molecule has large side groups and/or many branches, or it is irregular in structure, it cannot crystallize 
when the melted condition cools down. It remains disordered. These are the amorphous polymers.

The state of the polymer can be glassy, elastic and melted. In the glassy state, parts of the polymer macromolecule can only oscillate. By increasing the temperature, the internal energy is increased, the individual parts and segments of the molecules can move, and deform, but the relative position of the center of the mass of the molecular does not change; the polymer has a high degree of reversible deformation. This is a flexible state. As a result of further internal energy growth, a plasticized condition occurs where the molecules move relative to one another and the polymers flow. The transitions between the individual states occur at temperatures typical of the particular polymer (Bánhegyi 2005; Hargitai 2011; Miskolczi 2012). Since polymers do not have a specific molecular weight, but a density distribution within a range, the conversion temperature also influences the range. It is known that many amorphous polymers change from a glassy state to a rubbery, elastic state above a certain temperature, as they plasticize (Hatakeyama and Hatakeyama 2010; Medved 2010). The temperature range where the glassy to rubbery, plasticized state transformation occurs is the glass transition temperature $\left(\mathrm{T}_{\mathrm{g}}\right)$ (Back and Salmén 1982; Bánhegyi 2005; Hargitai 2011; Miskolczi 2012). The glass transition temperature can be examined by several methods (both static and dynamic): differential scanning calorimetry (DSC), differential thermal analysis (DTA) and thermogravimetric analysis (TGA), dynamic mechanical analysis (DMA/ DMTA), dielectric thermal analysis (DETA), and torsional pendulum analysis (Hatakeyama et al. 1972; Kelley et al. 1987; Wolcott 1989; Lenth and Kamke 2001; Miki et al. 2007; Hatakeyama and Hatakeyama 2010; Miki et al. 2007; Gellerstedt 2015; Kong et al. 2017).

The temperature required by lignin at glass transition $\left(\mathrm{T}_{\mathrm{g}}\right)$ is influenced by a number of factors, such as the presence of rigid phenolic side groups on the main chain, the presence of crosslinking, the number of bonds between chains, hydrogen bonds, its molecular weight, isolation method, species, lignin conformation, and thermal prehistory, etc. (Chow and Pickles 1971; Hillis and Rozsa 1978; Olsson and Salmén 1992, 1997; Lenth and Kamke 2001; Windeisen and Wegener 2008; Gellerstedt 2015; Furuta et al. 2008, 2010; Hatakeyama and Hatakeyama 2010). When dry, the differences in the glass transition temperature of cellulose, hemicellulose and lignin are not big: $200-250{ }^{\circ} \mathrm{C}$ for the amorphous region of cellulose, 150 to $220^{\circ} \mathrm{C}$ for hemicelluloses, and $205^{\circ} \mathrm{C}$ for lignin (Goring 1963; Back and Salmén 1982). These values are difficult to validate because hemicellulose and lignin degrade near this temperature (Schaffer 1973; Back and Salmén 1982). Lignin seems to be the most thermally stable component of wood, but various changes occur below $200{ }^{\circ} \mathrm{C}$ (Sehlstedt-Persson 2005). Lignin decomposes over a broader temperature range $\left(200-500^{\circ} \mathrm{C}\right)$ than cellulose and the hemicellulose. Degradation studies performed on different types of lignin showed an endothermic peak at $100-180{ }^{\circ} \mathrm{C}$, as a result of the elimination of humidity, followed by two exothermal peaks, the first from 280 to $390{ }^{\circ} \mathrm{C}$ and the second one around $420{ }^{\circ} \mathrm{C}$ (Brebu and Vasile 2010).

Many researchers have studied the effect of moisture content on the $\mathrm{T}_{\mathrm{g}}$ of extracted hemicelluloses and lignin (Goring 1963, 1971; Back and Salmén 1982; Irvine 1984) or in situ hemicelluloses and lignin (Irvine 1984; Kelley et al. 1987; Morsing and Hoffmeyer 1998). Moisture dramatically affected the $\mathrm{T}_{\mathrm{g}}$ (Goring 1963; Becker and Noack 1968; Sakata and Senju 1975; Back and Salmén 1982; Kelley et al. 1987; Wolcott 1989; Wolcott et al. 1990; Bouajila et al. 2006; Miki et al. 2007; Hatakeyama and Hatakeyama 2010; Sen et al. 2013). The structure of lignin is rich in phenolic hydroxyl and it offers the possibility to create intermolecular hydrogen bonds. Water molecules can break these hydrogen bonds and segmental motion can occur easily (Hatakeyama and Hatakeyama 1998, 2010). The $\mathrm{T}_{\mathrm{g}}$ of lignin decreases with increasing moisture content until the wood or the lignin reaches its water saturated point. The number of hydroxyl groups influences the amount of water bound to lignin (Hatakeyama and Hatakeyama 2010). The difference between the results could stem from the equilibrium and non-equilibrium moisture conditions. For example, Salmén (1984) maintained strict moisture control during the temperature changes, while Kelley et al. (1987) and Irvine (1984) conditioned the samples to an initial moisture content and then provided no explicit control for moisture content during the tests (Wolcott et al. 1990) (Table 1).

Softwoods contain more lignin than hardwoods, and there also are structural differences between softwood and hardwood lignin (Sehlstedt-Persson 2005). Softwood lignins have higher glass transition temperatures $\left(138-160{ }^{\circ} \mathrm{C}\right)$ while hardwood lignins have a lower $\mathrm{T}_{\mathrm{g}}$ range $110-130^{\circ} \mathrm{C}$ under dry conditions (Sen et al. 2013). The main structural differences between the two types of lignin is a lower content of free phenolic hydroxyl groups. A substantially higher content of methoxyl groups is found in hardwood and less in softwood lignins, and the hardwood lignins are less cross-linked than the softwood lignins (Olsson and Salmén 1992). The result of Horváth et al. (2011) contradicts though this argument above. They examined the thermal softening behavior of genetically modified aspen trees with reduced lignin content and/or increased S/G ratio, and their results suggest that the higher content of methoxyl groups and thus less cross-linked lignin did not alter the softening behavior of lignin. The modification of lignin can shift the $\mathrm{T}_{\mathrm{g}}$ : sulfonation of the lignin lowered the $\mathrm{T}_{\mathrm{g}}$ depending on the degree of sulphonation (Back and Salmén 1982) while lignin esterification decreases $\mathrm{T}_{\mathrm{g}}$ (Thiebaud and Borredon 1995; Lisperguer et al. 2009). Finally, yellow poplar juvenile wood 
Table 1 Moisture content effect on the glass transition temperature of lignin

\begin{tabular}{|c|c|c|}
\hline References & Moisture content & $\mathrm{T}_{\mathrm{g}}\left({ }^{\circ} \mathrm{C}\right)$ \\
\hline Urakami and Nakato (1966) & Sat & 50 \\
\hline Stelte et al. (2011b) & Sat & 53 \\
\hline Nakajima et al. (2008) & Sat & 60 \\
\hline Kelley et al. (1987) & 30 & 60 \\
\hline Östberg et al. (1990) & 25 & 60 \\
\hline Irvine (1984) & 25 & 62 \\
\hline Wolcott (1989); Wolcott et al. (1990) & $10-15 \%$ & 70 \\
\hline Hillis and Rozsa (1978) & Sat & $72-128$ \\
\hline Gašparík and Barcík (2014) & Sat & $77-128$ \\
\hline Becker and Noack (1968) & Sat & 78 \\
\hline Furuta et al. (2000) & Sat & 80 \\
\hline Furuta et al. (1997) & Sat & 80 \\
\hline Sadoh (1981) & Sat & 80 \\
\hline Kong et al. (2017) & $20 \%$ & $80-94$ \\
\hline Salmén (1984) & Sat & $82-100$ \\
\hline Uhmeier et al. (1998) & Sat & 85 \\
\hline Östberg et al. (1990) & 6.5 & 86 \\
\hline Goring (1963) & $27 \%$ & 90 \\
\hline Stelte et al. (2011b) & Sat & 91 \\
\hline Bouajila et al. (2006) & Sat & $\sim 100$ \\
\hline Irvine (1984) & 7 & 108 \\
\hline Sen et al. (2013) & Dry & $110-160$ \\
\hline Jonsson (2009) & $8-15 \%$ & $110-135$ \\
\hline Back and Salmén (1982) & Sat & 115 \\
\hline Kelley et al. (1987) & 5 & 115 \\
\hline Atack (1972) & Sat & $120-135$ \\
\hline Koran (1979) & - & 125 \\
\hline Wert et al. (1984) & Dry & $132-192$ \\
\hline Ibach (2010) & - & 170 \\
\hline Goring (1963) & Dry & 195 \\
\hline Back and Salmén (1982) & Dry & 205 \\
\hline Sadoh (1981) & Dry & 235 \\
\hline
\end{tabular}

exhibited a lower $\mathrm{T}_{\mathrm{g}}$ than mature wood. In case of southern pine, this trend was reversed (Lenth 1999).

Of course, other wood constituents in a native wood cannot be separated from lignin. The softening temperature of native hemicellulose under dry conditions is high, around $180^{\circ} \mathrm{C}$ (Goring 1965; Alfthan et al. 1973; Back and Salmén 1982; Olsson and Salmén 2003). Water works like a plasticizer and decreases the glass transition temperature: at $20 \%$ water content it is around $50{ }^{\circ} \mathrm{C}$, at $30 \%$ it is around room temperature (Back and Salmén 1982; Olsson and Salmén 2003; Placet et al. 2008; Navi and Sandberg 2012). The amorphous regions of cellulose behave similarly. During veneer production and bending, the wood is saturated with water, and during pellet production, it also contains a significant amount of water. During these processes, hemicellulose is already above its $T_{\mathrm{g}}$, so raising the temperature does not cause a change in the hemicellulose structure. On the other hand, as the wood dries, the lignin softening is reduced, and the hemicellulose softening becomes more important. Most of these processes take place at elevated temperatures, which will dry wood. However, with wood welding, binderless board manufacturing or surface densification, the temperature is usually above $180{ }^{\circ} \mathrm{C}$, which softens both hemicellulose and lignin. Because there is more than one parameter involved, the plasticization does not occur at a fixed temperature, the $\mathrm{T}_{\mathrm{g}}$ is also affected by pressure, and as certain operations (e.g. pellet production) take place at high pressure, the increase in the $T_{g}$ is not negligible. Based on previous works, a linear relationship can be established between the $\mathrm{T}_{\mathrm{g}}$ and pressure (Ichihara et al. 1971; Zoller 1982; Zoller et al. 1989; Andrews and Gruclke 1999; Krevelen 2009). All in all, the importance of lignin is highlighted in the literature, so we can also study these wood industry processes examining lignin.

This type of wood softening - mainly the lignin—is used in several industrial processes, namely: pellet manufacturing, binderless panel manufacturing, wood welding, wood bonding, wood surface compacting, and veneer manufacturing by peeling. Of course, during these industrial processes, in addition to softening, other physical and chemical reactions take place, all of which contribute to the end result of the process. The aim is not to describe these reactions in detail, but rather to provide a summary of the industrial processes where lignin softening may play a role.

\section{Wood welding}

Frictional welding is a relatively new technology for creating wood joints but this technique is widely used in the plastics industry (Ganne-Chédeville et al. 2006). Sutthoff et al. (1996) made the first efforts to join wood by pressure and frictional heat. During the welding process, no other material is added to the system, the welded pieces of wood are frictioned together to provide the necessary energy. In doing so, the components of wood (lignin, cellulose and other polymers) are melted and partially decomposed by heat and are subject to chemical reactions during the process.

At the beginning of the welding process, Coulomb friction causes the surfaces to heat up. After a few seconds (3-10 s), at a temperature of about $320-350{ }^{\circ} \mathrm{C}$, the wood surfaces start to decompose at the increased temperature. The temperature of $180^{\circ} \mathrm{C}$ is reached quickly at the interface/surface but at less than $1 \mathrm{~mm}$ below the interface, the temperature is still $20^{\circ} \mathrm{C}$ lower $\left(160^{\circ} \mathrm{C}\right)$. The wood next to the rubbed surfaces starts to soften, forming a viscous film. After reaching the maximum temperature about $420-450{ }^{\circ} \mathrm{C}$, the frictional movement is terminated, and the joined parts 
are held together. The final cooling down leads to solidification of the interfacial film forming the connection between the wood parts (Stamm et al. 2005b). No preparation of the welded surfaces is required and the time necessary to complete the bond is shorter than one minute (Stamm et al. 2005b).

The mechanism of welding, in addition to the chemical reactions that take place due to the temperature-induced softening, is chemical activation, flowing and solidification of the intercellular material, mainly amorphous polymers: lignin and hemicelluloses (Stamm et al. 2005a; Windeisen and Wegener 2008). This flow of material induces high densification of the bonded interface (Leban et al. 2005; GanneChédeville et al. 2006; Pizzi 2017). The physical entanglement of the fibers interconnected as a result of friction can improve the connection. In the brief pressure-holding phase immediately after welding, chemical reactions occur. The main reactions are the formation and self-condensation of furfural and the cross-linking reaction of lignin with carbohydrate-derived furfural (Pizzi 2017).

Sun et al. (2010) suggested that the chemical changes when applying friction welding are similar to changes during fast pyrolysis at a lower pyrolysis temperature. This is a transformation of a nonvolatile compound into a volatile mixture by heat in the absence of oxygen. During these processes, bonds are broken, free radicals are formed, which re-polymerize and create side-chains (Kawamoto 2017). In these temperature ranges, only the amorphous components of wood are affected, particularly lignin and hemicelluloses, and to a lesser extent, amorphous cellulose. First, hemicelluloses degrade through acid hydrolysis and dehydration, which starts above $100{ }^{\circ} \mathrm{C}$, but the weight loss of hemicelluloses takes place mainly in the temperature range of $220-315^{\circ} \mathrm{C}$. The mono- and oligosaccharides change into furfural and 5-hydroxymethylfurfural as they dehydrate. Xylan is more affected than mannan, because the glycosidic bonds of xylan are more susceptible to acidic attack (Stamm et al. 2005a). The changes of the amorphous cellulose are similar to those of hemicelluloses and levoglucosan and furan and the same kind of compounds produced. The effects of heat on lignin occur within a wide temperature range. The proportion of the $\mathrm{C}-\mathrm{C}$ and $\mathrm{C}-\mathrm{H}$ bonds decreases, while those of $\mathrm{C}-\mathrm{OH}, \mathrm{C}-\mathrm{O}-\mathrm{C}, \mathrm{C}=\mathrm{O}$ and $\mathrm{O}-\mathrm{C}-\mathrm{O}$ increase. First $-\mathrm{OH}$ groups are thermo-oxygenated and aldehydes are formed. Chemical substances which contain oxygenated functionality are also formed and move to the welding zone: terminal hydroxymetyl groups from the G-type lignin side chains leave in the form of formaldehyde, which then can contribute to condensation reactions of lignin fragments generated during the welding. The amount of typical bonds of phenilpropane units decreases, while furfural and furan derivatives react with the lignin (Gfeller et al. 2004; Kanazawa et al. 2005; Stamm et al. 2006; Delmotte et al.
2008; Belleville et al. 2013). During friction, a new lignincarbohydrate complex is formed from the condensation reaction between lignin fragments and furfural derivatives from hemicelluloses (Sun et al. 2010). Belleville et al. (2018) found that a higher proportion of lignin seems to be favorable to condensation reactions during the welding process. According to another observation, fatty acids, terpenoids and other extractive compounds form covalent bonds with hydroxyl groups of other compounds. There is a degradation of fatty acids, which deform to carboxyl acids, mainly citric acid, which can improve the mechanical properties through chemical linkages (Belleville et al. 2018). The work of Ganne-Chédeville et al. (2008) summarizes the processes that take place at different temperatures during welding. The main components of the smoke emitted during welding are water vapor, $\mathrm{CO}_{2}$ and decomposed compounds from wood polymeric carbohydrates and from lignin (Omrani et al. 2008). Delmotte et al. (2009) found that increasing the welding frequency from 100 to $150 \mathrm{~Hz}$, the oxidation of the components decreased due to the much shorter welding time, which improved the joint strength.

Hardly damaged fibres, tracheids were observed immersing in a mass of molten polymer. The welded bondline is then composed of a mass of entangled long wood cells immersed in a matrix of amorphous, fused intercellular material, mostly lignin but also including some hemicelluloses. The bonding line separates into (1) a melting zone, where the wood polymers melt, decompose and partly char; (2) to a fully plasticized zone and (3) a deformed zone, where the polymers are plasticized and the cells deform, and (4) a partially deformed region, where the cells are only slightly affected (Ganne-Chédeville et al. 2006).

The welding processes can be classified as linear, orbital and rotational friction welding (Ruponen et al. 2015). In linear welding, the wood samples are joined to each other with a 1.3-2 MPa pressure. The samples are vibrated with a displacement amplitude of about $2-3 \mathrm{~mm}$ and a vibration frequency of $100-150 \mathrm{~Hz}$ in the plane of the joint (Leban et al. 2005; Pizzi 2017). Specimens 1.0-1.8 m long can be welded and the welding takes $1.5-5 \mathrm{~s}$ and the holding time, still under pressure, after vibration has stopped, is $5 \mathrm{~s}$ too (Pizzi 2017). After linear welding, 10 to $11 \mathrm{MPa}$ tensile strength was measured (Leban et al. 2005). With high-speed rotation welding, wooden dowels (usually $10 \mathrm{~mm}$ diameter) are inserted at high rotation speed into a smaller diameter pre-drilled hole (usually $8 \mathrm{~mm}$ diameter). In dowel welding, generally, cylindrically fluted beech dowels $10 \mathrm{~mm}$ in diameter are used (Pizzi 2017). For best results, the drill rotation rate must be between 1500 and $1600 \mathrm{rpm}$. When bonding is achieved (1-3 s), the rotation of the dowel is stopped, and the pressure is briefly maintained.

The quality of a friction welding joint correlates with several welding parameters, such as welding pressure, 
frequency, time, holding pressure and time, amplitude or displacement, wood species, orientation of the grains, equilibrium moisture content and specimen dimensions, chemical composition etc. (Kanazawa et al. 2005; Properzi et al. 2005; Ganne-Chédeville et al. 2006, 2008; Delmotte et al. 2009; Omrani et al. 2009; Župčić et al. 2014; Ruponen et al. 2015; Belleville et al. 2018; Zhu et al. 2019).

The limitation of linear welded wood is that the welded joint has low water resistance in other words the joint is more water sensitive. Water resistance can be increased by selecting appropriate welding parameters (Mansouri et al. 2009; Vaziri et al. 2010, 2011; Vaziri 2011). In contrast to linear vibration welding, the rotation-welded dowel joints are completely resistant to water when immersed, which shows that proper geometry of the joint can improve water resistance (Pizzi et al. 2006).

\section{Pellet manufacturing}

Lignocellulosic materials can be densified by pelletizing, briquette or cube making. During this process, the particles are pressed together by applying a mechanical force to create inter-particle bonding (Tumuluru et al. 2010; Kaliyan and Morey 2010). The product becomes denser, more manageable and usually more durable. The name 'pellet' is usually used for products less than $15 \mathrm{~mm}$ in diameter, while 'briquette' generally refers to larger dimensions. Several researchers examined the compression process of different raw materials such as wood, wood waste and bark (Chin and Siddiqui 2000; Demirbaş et al. 2004; Lehtikangas 2001; Li and Liu 2000; Rhén et al. 2005, 2007), forest residues (Lehtikangas 1999; Acda and Devera 2014), straws, grasses (wheat, barley, corn etc.) (Smith et al. 1977; Wamukonya and Jenkins 1995; Demirbaş 1999; Kaliyan and Morey 2006; Mani et al. 2004,2006a,, b; Ndiema et al. 2002; Olsson 2006; Shaw 2008; Gilbert et al. 2009; Lehmann et al. 2012; Stelte et al. 2012; Lee et al. 2013), alfalfa (Adapa et al. 2002; Tabil and Sokhansanj 1996a, b, 1997; Fasina and Sokhansanj 1995), olive cake (waste) (Al-Widyan et al. 2002; Yaman et al. 2000), palm fiber and shell (Husain et al. 2002; Tenorio et al. 2016; Wattana et al. 2017). Since pellet production has been studied most frequently and in many detail, this is described further below. Thereby, most statements remain true for other densifying procedures (Tumuluru et al. 2010). There are many methods for characterizing the quality of a pellet, often referred to as the durability of the pellet. There are no standards given, but most methods model the impact and the shearing stresses as such (Oveisi-Fordiie 2003).

During the process, the size of the feedstock material is typically reduced by milling or grinding, and conditioned to an appropriate moisture content either by drying or moisturizing. In most cases, the particles of raw material are forced through a channel. Usually, in a pellet mill, the pressure is 100-150-200 MPa (Kaliyan and Morey 2009). The pelletizing process generates heat that maintains the temperature of the operating die at $110-130{ }^{\circ} \mathrm{C}$ (Nielsen et al. 2009). Lignin and extractives in wood and other lingocellulosic materials have been reported to function as natural binding agents during the pressing of the pellets (Bradfield and Levi 1984; Alakangas and Paju 2002; Gilbert et al. 2009; Nielsen et al. 2010; Berghel et al. 2013). During pelleting, in the raw material with $8-15 \%$ moisture content, the lignin softens around $110-135^{\circ} \mathrm{C}$ (Lehtikangas 2001 ; Kuokkanen et al. 2011; Kaliyan and Morey 2009), the drier raw material needs higher temperatures (Zhanbin 2003). According to Anglès et al. (2001), the following reactions occur during pelleting: Partial hydrolysis of cellulose and hemicellulose; and then partial hydrolysis of lignin leading to a lower molecular weight material. At high steam temperatures, some low molecular weight lignin melts, flows, and partially coalesces into droplets. The thermally softened lignin contributes to the strength characteristics of pellets and briquettes made of lingocellulosic materials (Granada et al. 2002; Serrano et al. 2011). As the pellets cool, lignin hardens again and the pellet strength increases. Cooling stabilizes the pellets and stiffens the lignin melted on the surface of the pellets, and hence, the shape of the pellets remains unchanged (Alakangas and Paju 2002). There is a positive relationship between pellet durability and lignin content (Lehtikangas 2001; Castellano et al. 2015). The lignin content of different straws is generally lower than in wood, and therefore straws produce less durable pellets (Lehmann et al. 2012; Stelte et al. 2012; Lee et al. 2013).

Macroscopically, two binding mechanisms can be distinguished: solid bridges between particles (Stelte et al. 2011a; Serrano et al. 2011) and other bonding without a solid bridge (Kaliyan and Morey 2010). Without a solid bridge, forces between particles can form bonds by hydrogen bridges, van der Waals' forces, electrostatic and magnetic forces if the particles are close enough to each other. Due to the application of high pressures and temperatures, solid bridges can develop by diffusion of molecules from one particle to another at the points of contact and be formed by a chemical reaction, hardening of the binders, and solidification of the melted components (Kaliyan and Morey 2010). Bio-based binding materials such as starch, protein, lignin, and pectin in the raw materials under high pressure are pressed out of the raw material, and cause inter-particle bonding. To produce a sufficient bonding area, especially in the absence of a binder, the plasticization of wood polymers above their glass transition temperatures is necessary (Back, 1987). Chung (1991) suggested that at the microscopic level, there are two criteria for bonding between particles: the molecules should be in contact of closer than $9 \AA$ and the maximum attractive force should have a minimum potential energy. 
When the maximum attractive force is near the minimum potential energy, chemical bonding is established. Pressure, heat above glass transition temperature may promote adhesion by increasing the molecular contact. Samuelsson et al. (2012) added some further bonding mechanisms, they found that interfacial forces and capillary pressure in movable liquid surfaces, adhesion and cohesion forces, and mechanical interlocking between particles can also strengthen internal bonding.

Several factors were found to influence the process and the result of the densification experiments (Rehkugler and Buchele 1969; Bradfield and Levi 1984; Granada et al. 2002; Shaw 2008; Kaliyan and Morey 2009). Increasing the temperature and moisture content (MC) decreased the energy requirements for pellet manufacturing (Nielsen et al. 2009). A significant part of the energy for the pelletizing process is used to force the compressed sawdust from the surface of the die into the pressing channels. Increasing the temperature of the die increases the pellet density, decreases the dimensional expansion, and increases the tensile strength of the pellets. The application of heat to the aggregated material during its formation confers greater cohesion to it, because at temperatures between 80 and $200{ }^{\circ} \mathrm{C}$ lignin becomes softer, and after cooling, it functions as a thermoplastic glue, depending on the materials (Kaliyan and Morey 2006; Relova et al. 2009; Theerarattananoon et al. 2012).

Moisture acts as one of the binding agents in the pelleting process (Lehtikangas 2001), so the moisture content of the raw material is of high relevance. Decreasing the moisture content increases the pellet density as well as its dimensional stability (Shaw 2008). Increasing the moisture content to between 10 and $13 \%$, the mechanical durability increases; a further increase of moisture causes a decline in durability (Wilfried et al. 2006; Ahn et al. 2014) because of the lignin softening and excessive vapor formation.

Decreasing the particle size increases the pellet density, decreases their expansion, which means higher dimensional stability, and increases the tensile strength of the pellets. A high surface area/volume ratio in each particle allows better penetration of moisture and heat, and consequently improves its strength properties (Lehtikangas 2001).

The biochemical characteristics of the raw material also are very important. Higher lignin and extract content have a positive effect on the durability of pellets (Bradfield and Levi 1984; Lehtikangas 2001; Stelte et al. 2011a; Serrano et al. 2011; Filbakk et al. 2011). Several studies showed that pellets produced from bark have excellent durability (Lehtikangas 2001; Filbakk et al. 2011; Ahn et al. 2014). Bark usually contains higher levels of lignin than wood (Filbakk et al. 2011), and contains higher levels of extractives. The effect of the bark is unclear; Ahn et al. (2014) found that up to $10 \%$ bark reduced the durability of larch pellets. Waxes on the surface of straw produced a weak waxy boundary layer, resulting in lower strength (Nielsen et al. 2009; Samuelsson et al. 2012; Castellano et al. 2015).

Pretreatment of the raw material generally increases the pellet density and durability.

During the steam pretreatment, the hemicellulose was removed and/or hydrolysed. As a result, a higher relative amount of lignin was present and this lignin was more readily available for binding, thus producing superior pellets (Shaw 2008). Zandersons et al. (2004) suggested that during the steam explosion process, the lignin is activated and the cellulosic structure is changed which facilitates the formation of new bonds. Chemical activation with hydrogen peroxide resulted in a lower mechanical durability and reduced heating value, but thermal activation trials indicated a positive effect on their durability (Wilfried et al. 2006). By pre-treatment with microwave irradiation, the ester bonds between the lignin and hemicelluloses are disrupted, and the free lignin can create additional bonds thus increasing the strength and durability of the densified product (Thomas et al. 1998; Lu et al. 2014).

Pressing aids and adhesives can also increase the durability and strength of pellets (Obernberger and Thek 2004; Wilfried et al. 2006; Kuokkanen et al. 2011; Berghel et al. 2013; Ahn et al. 2014; Lu et al. 2014).

In summary, a high lignin content and optimum MC coupled with a high pelleting temperature tend to improve biomass pellet durability (Relova et al. 2009; Whittaker and Shield 2017).

\section{Wood surface densification}

Compression is used to increase density and change the surface properties of wood, for example hardness (Donghua et al. 2010; Petrič 2013). Densification of wood can also be achieved by impregnating its void volume with polymers, molten natural resins, waxes, sulphur, and even molten metals (Kutnar and Šernek 2007). Sandberg and Navi (2007) made a summary of these topics. The process of densifying wood by compression requires four steps (Kutnar and Šernek 2007; Rautkari et al. 2011): (1) plasticization of the cell wall, (2) compression perpendicular to the grain in the softened state, (3) cooling and drying in the deformed state, and (4) fixation of the deformed state to eliminate the shape memory effect. The density is increasing, the color of the wood becomes darker and the EMC is reduced markedly (Donghua et al. 2010; Arruda et al. (2015).

Firstly the cell wall should soften. The temperature should be at least $25^{\circ} \mathrm{C}$ higher than $\mathrm{T}_{\mathrm{g}}$ of lignin, between 80 and $140{ }^{\circ} \mathrm{C}$, and the moisture content near the saturation point. Under these conditions, lignin, hemicelluloses and the semi-crystalline cellulose can be deformed easily. Hemicelluloses in the cell wall are softened (at $54-56{ }^{\circ} \mathrm{C}$ ), which 
decreases the stiffness of wood. This enables wood fibers to adapt their cross-sectional shape to the applied forces. The softening of lignin (at $72-128^{\circ} \mathrm{C}$ ) in the cell wall and middle lamellae permit further cross-sectional movement within and between the fibers (Kutnar and Šernek 2007; Kutnar et al. 2009; Tu et al. 2014; Rautkari et al. 2011).

Compression changes the wood morphology as the cell walls buckle and the volume of void spaces gets reduced while a non-uniform density profile across the sample is generated as the surface becomes denser. A higher degree of densification is achieved by a larger reduction in the void spaces of the wood and at high pressure, the volume of void spaces in the specimens is drastically reduced, and cell lumens are deformed. Usually the cells are deformed without fracturing the cell walls, while the rays appear to buckle (Kutnar et al. 2009).

When compressed wood is exposed to water, it tends to regain its original dimensions. This effect occurs because internal stresses are introduced into the cell walls during compression. This memory effect or spring back can be completely eliminated by different methods. Heat treatment and steam treatment are the most common ones (Morsing and Hoffmeyer 1998; Wolcott and Shutler 2003; Kutnar et al. 2009). Kutnar and Kamke (2012a, b) suggested that the stabilization of compressive deformation was more successful when wood was compressed under saturated steam at $170{ }^{\circ} \mathrm{C}$. In addition, heat treatment at $200{ }^{\circ} \mathrm{C}$ adds some improvement to dimensional stability.

Sandberg et al. (2013) published a review article about thermo-hydro and thermo-hydro-mechanical wood processing, where also other applications of densified wood are discussed.

\section{Binderless boards}

Due to its environmentally friendly properties, many researchers tried to produce fiber or particle boards without adhesive or using bio-based adhesives such as sugars or lignin. Wood-based binderless fibreboards without synthetic resin binders have been produced for at least 80 years: several types of bio-raw material were used for binderless boards, for example wood bark (Chow 1975; Wellons and Krahmer 1973; Geng et al. 2006; Gao et al. 2011), rice and wheat straw (Zhao et al. 2013; Kurokochi and Sato 2015a, b), kenaf (Xu et al. 2004), banana stems (Nongman et al. 2016), coconut husks (van Dam et al. 2004; 2006), bagasse (Mobarak et al. 1982), oil palm (Hashim et al. 2012; Baskaran et al. 2015), soybean straw (Song et al. 2020) and bamboo (Shao et al. 2009) etc. Recently, a review work on binderless fibreboards from agricultural residues was published summarizing the related studies (Nasir et al. 2019).
Several parameters influence the physical and mechanical properties of wood panels: chemical composition (Widyorini et al. 2005; Lui et al. 2018), particle size and geometry (Widyorini et al. 2011; Kurokochi and Sato 2015a, b; Lui et al. 2018; Ahmad et al. 2019; Ferrandez-Villena et al. 2020), pressing temperature (Okuda et al. 2006a; Gao et al. 2011; Hashim et al. 2011; Boon et al. 2013; Milawarni et al. 2019; Song et al. 2020), pressing time (Xu et al. 2006; Gao et al. 2011; Boon et al. 2013; Ferrandez-Villena et al. 2020), pressure (Boon et al. 2013); water content (Widyorini et al. 2005; Xu et al. 2006), and pretreatment (Xu et al. 2006; Takahashi et al. 2010), etc. Trichomes and wart-like protuberances on the epidermis of herbaceous straw might inhibit the bonding between particles. Wax-like substances on the epidermis of rice straw might contribute to the water resistance of the board but inhibited the adhesion of the particles (Kurokochi and Sato 2015a, b).

The chemical composition of the different biomasses is similar and their main components are the same: cellulose, lignin, hemicelluloses. The bonds between the bioparticles are based on chemical and physical interactions occurring during the hot pressing between various components of the particles or their derivatives (Suchsland and Woodson 1987; Yelle 2001; Hubbe et al. 2018). In fiberboard production, during thermomechanical pulping, woodchips are converted to lignin-covered fibers by shearing wood fibers along the lignin-rich middle lamellae (Felby et al. 1997; Kharazipour et al. 1998). Goring (1971), Yelle (2001), van Dam et al. (2004), Bouajila et al. (2005), Okuda et al. (2006a, b), Halvarsson et al. (2009), Wang et al. (2017) and Laine et al. (2019) suggested that lignin has an important role in the production of binderless boards due to the softening of lignin at elevated temperatures and under pressure, fibers with lignin-rich surfaces fuse together as the softened lignin molecules flow from one fiber surface to another one, and possibly form covalent bonds too. If the water content of the raw material is above or near the saturation point, the $\mathrm{T}_{\mathrm{g}}$ of the cell wall polymers is relatively low. However, as the temperature of the materials rises during hot pressing, the water content of the particles or fibers decreases and as a result the softening temperature also increases. The $T_{g}$ of the polymers increases around $200{ }^{\circ} \mathrm{C}$. The polymers of the raw material are in a plasticized state during a limited period and this period depends on their position within the panel (Bouajila et al. 2005). Water leaves the panel near its sides, and the $\mathrm{T}_{\mathrm{g}}$ rapidly increases. At elevated temperatures, irreversible softening of the lignin occurs due to dehydration and cross-linking reactions (van Dam et al. 2004), so the role of the softened lignin cannot be separated from the chemical changes.

Several chemical reactions were observed during hot pressing: hydrolysis of the hemicelluloses occurs (Runkel and Wilke 1951; Xu et al. 2006; Zhang et al. 2015), organic 
acids, mainly furfural, are formed, but the amount of the resulting furfural depends on the chemical composition of the raw material and its water content, temperature etc. (Rowell and McSweeny 2008; Tshabalala et al. 2012). The monomers generate lignin-furfural linkages or undergo selfpolymerization during the pressing, which provide the main self-bonding strength of binderless fiberboards (Suzuki et al. 1998; Zhang et al. 2015).

The surfaces of the particles and fibers can be activated by different pretreatments, which increase the amount of the chemical bonds. Fenton's reagent contains ferrous chloride and hydrogen peroxide; hydroxyl radicals are generated by decomposition of hydrogen peroxide with the assistance of ferrous ions. In the end, reactive components formed in lignin and the properties of the boards improved (Kharazipour et al. 1998; Halvarsson et al. 2009; Zhang et al. 2015).

Enzymatic systems can also activate lignin on fiber surfaces by generating free radicals, and create bonds between the surfaces of fibers and particles without the use of conventional adhesives (Felby et al. 1997; Hüttermann et al. 1998; Kharazipour et al. 1998). Laccase enzyme can oxidize the lignin and stable lignin radicals are formed (Hüttermann et al. 1998; Felby et al. 2004; Pereira et al. 2005; Nyanhongo et al. 2010). This lignin radical reacts with cellulose and other lignin molecules, so it can be used to produce composite materials using lignin and fibers. Wet process boards produced in this manner have shown equal or better bonding properties than boards produced with phenolic adhesives (Hüttermann et al. 1998). The enzymatic activation of lignin for lignocellulosic products such as MDF and particleboard can improve the self-bonding properties of the biomass by oxidation of their surface lignin before being fabricated into boards (Widsten and Kandelbauer 2008).

Panel properties can be improved by steam explosion (Suzuki et al. 1998; Anglès et al. 1999, 2001; Shao et al. 2009; Gao et al. 2011), because lignin droplets were observed on the surface of the fibers (Anglès et al. 1999). Steam injection during pressing has a similar result.

Due to the physical and chemical bonds formed by lignin, the addition of lignin to the raw material can improve the properties of the panels (Anglès et al. 2001; Hemmilä et al. 2013; Milotskyi et al. 2019).

\section{Solid wood bending}

Wood bending is one of the oldest wood processing techniques. Long experience has evolved from the practice of bending techniques and skilled craftsmen can apply them. Naturally, at normal moisture content and temperature, every wood has some plasticity, but this plasticity is not enough to bend solid wood. Heat and moisture make certain species of wood sufficiently plastic for bending operations. In general, hardwoods are more readily softened than softwoods, and certain hardwoods more so than others. The purpose of all plasticizing treatments is to soften wood sufficiently to enable it to take the compressive deformation necessary to make a curve (Peck 1957). Hot wood is more plastic than cold wood, and wet wood is more plastic than dry wood. The plasticity of wood can be increased by increasing the moisture and/or temperature of the wood. Together, heat and moisture can produce a degree of plasticity 10 times that of dry wood at normal temperatures (Peck 1957). Hot water and steam are commonly used treatments to prepare wood for bending.

The glass transition temperature $\left(\mathrm{T}_{\mathrm{g}}\right)$ of the lignin in moist wood is $80-100{ }^{\circ} \mathrm{C}$. Above $\mathrm{T}_{\mathrm{g}}$, the lignin undergoes thermoplastic flow and resets in the modified configuration when cooling (Nakajima et al. 2009; Ibach 2010; USDA 2010).

The temperature of saturated steam at atmospheric pressure, about $100{ }^{\circ} \mathrm{C}$ or boiling or nearly boiling water, is generally sufficient to plastify wood for bending. In this condition, the viscosity of the lignin decreases, which makes connections between the cellulose micro- and macrofibrils (Angelski 2014). If the raw material has a 20-25\% moisture content, no additional moisture is needed, even for severe bends (Peck 1957). Technically these methods belong to the hydrothermal treatment. If thermal treatment is used, water or steam has no impact on the raw material. This method is implemented by contact of hot metal surfaces (Angelski 2014). In another method, high frequency heating is used (Sandberg and Johansson 2005). The high-frequency microwave heating of wood is also used for plasticization (Ibach 2010; Gašparík and Gaff 2013). A longer plasticizing time increases the amount of microwave energy delivered to wood, on the other hand, the higher amount of energy also causes a higher moisture loss. Therefore, a suitable plasticizing time should be chosen (Gašparík and Gaff 2013).

Some chemicals can also soften wood. When chemicals are used for plasticization, the connections between the matrix (lignin) and cellulose and the ties between the cell walls loosen.

The chemical plasticization commonly uses water solutions of ammonia, urea, dicyandiamide, ethylenediamine and liquid ammonia (FPL 1943; Schuerch 1963; Pentoney 1966; Bariska 1969; Davidson and Baumgardt 1970; Bariska and Schuerch 1977; Angelski 2014; Suleman 2015; Šprdlík et al. 2016). Ammonia is a solvent with a similar molecular size but a greater hydrogen bonding capacity than water. Liquid ammonia can swell and soften wood more than water. It breaks hydrogen bonds with all the components of the cell walls and creates new hydrogen bonds, not only with hemicellulose and lignin, but it can also separate the chains of the crystalline cellulose. When the ammonia evaporates, 
new hydrogen bonds are formed in new positions and a new shape form.

\section{Veneer manufacturing}

Several factors have effects on veneer manufacturing and veneer quality (Olufemi 2012). Successful veneer production requires wood softening. The heating of green wood prior to peeling has traditionally been accomplished by soakingimmersing the whole logs in hot water basins-or by steaming them in vats. In both processes, water, as an integral part of wood, makes an ideal medium for heat transfer into wood (Daoui et al. 2007). The energy required for peeling can be reduced if less energy is required to move the cutting knife (Marchal et al. 2009; Dupleix et al. 2012; Dupleix 2013; Xu et al. 2017). If the shear strength of the wood decreases, it is sufficient to exert less pressure on the knife during peeling (Bédard and Poulain 2000). This reduces the power consumption and reduces wear of the tools (Marchal et al. 2004) and the quality of the veneer is improved reducing the formation of lathe checks and other surface quality defects (Lutz 1960; Aydin et al. 2006; Dundar et al. 2008; Marchal et al. 2009; Dupleix et al. 2012; Olufemi 2012; Rohumaa et al. 2016a, b, c; Frayssinhes et al. 2019).

During soaking or steaming the wood softens, and the deformability of wood increases (Baldwin 1975; Bardet et al. 2003; Yamauchi et al. 2005). Under optimal conditions, shallower lathe checks form (Rohumaa et al. 2016a, b, c; Frayssinhes et al. 2019). For this purpose, the temperature should exceed the glass transition temperature $T_{g}$, of lignin at the $\mathrm{MC}$ of green wood across the log. This temperature is lower than the $T_{g}$ of cellulose, while hemicelluloses are already above their $\mathrm{T}_{\mathrm{g}}$ (Engelund et al. 2013; Navi and Sandberg 2012). Therefore, lignin changes have the greatest influence on the behavior of wood. Reaching the $T_{g}$ of lignin also fluidizes wood resins and softens knots, which increases tool life. Rohumaa et al. (2017) suggested that the logs not only soften by heat, but irreversible changes occur in the wood material.

\section{Stress relaxing}

Heating logs in water or saturated steam relieves growth stress (Skolmen 1967). The temperatures of Eucalyptus grandis logs were determined and correlated with the cracks in the boards during steaming. Thermocouples were inserted in the centers of the logs, registering their temperatures during steaming at $90{ }^{\circ} \mathrm{C}$. It was found that the lengths of the cracks significantly decreased in logs that reached the glass transition temperature (Calonego et al. 2010).

\section{Conclusion}

We have seen that lignin softening plays a role in a variety of woodworking processes, which are basically divided into two groups. The first group includes processes where lignin softens or possibly liquefies, and the soft lignin penetrates into the gaps of adjacent particles and cell walls, and acts as an adhesive. This includes wood welding, the manufacture of binderless boards or manufacturing pellets. The other group consists of processes where the wood has to undergo some deformation and therefore the cell walls and the materials that compose the cell wall must move relative to one another. This group includes veneer manufacturing, solid wood bending and surface densification.

The referred 257 articles show the great effort of scientists to explore the composition characteristics, and behavior of the components of wood, especially focusing on lignin.

Acknowledgements The work was carried out as part of the "Sustainable Raw Material Management Thematic Network-RING 2017", EFOP-3.6.2-16-2017-00010 project in the framework of the Széchenyi 2020 Program. The realization of this project is supported by the European Union, co-financed by the European Social Fund.

Funding Open access funding provided by University of Sopron.

Open Access This article is licensed under a Creative Commons Attribution 4.0 International License, which permits use, sharing, adaptation, distribution and reproduction in any medium or format, as long as you give appropriate credit to the original author(s) and the source, provide a link to the Creative Commons licence, and indicate if changes were made. The images or other third party material in this article are included in the article's Creative Commons licence, unless indicated otherwise in a credit line to the material. If material is not included in the article's Creative Commons licence and your intended use is not permitted by statutory regulation or exceeds the permitted use, you will need to obtain permission directly from the copyright holder. To view a copy of this licence, visit http://creativecommons.org/licenses/by/4.0/.

\section{References}

Acda MN, Devera EE (2014) Physico-chemical properties of wood pellets from forest residues. J Trop Sci 26(4):589-595

Adapa PK, Tabil LG, Schoenau GJ, Crerar B (2002) Compression characteristics of fractionated alfafa grinds. Powder Handl Process 14(2):252-259

Adler E (1977) Lignin chemistry—past, present and future. Wood Sci Technol 11(3):169-218

Ahmad Z, Tajuddin M, Maleque MA, Halim Z (2019) Effects of particle sizes on the properties of binderless boards made from rattan furniture waste. J Eng Sci 15:49-61. https://doi.org/10.21315/ jes2019.15.5

Ahn BJ, Chang H, Lee SM, Choi DH, Cho ST, Han G, Yang I (2014) Effect of binders on the durability of wood pellets fabricated from Larix kaemferi C. and Liriodendron tulipifera L. sawdust. Renew Energy 62:18-23. https://doi.org/10.1016/j.renen e.2013.06.038 
Alakangas E, Paju P (2002) Wood pellets in finland-technology, economy and market. OPET Report 5. Jyväskylä VIT Processes, 64 pp + app. $21 \mathrm{pp}$

Alfthan E, de Ruvo A, Brown W (1973) Glass transition temperatures of oligosaccharides. Polymer 14(7):329-330. https://doi. org/10.1016/0032-3861(73)90127-4

Al-Widyan MI, Al-Jilal HF, Abu-Zreig MM, Abu-Hamdeh NH (2002) Physical durability and stability of olive cake briquettes. Canad Biosyst Eng 44:341-345

Andrews RJ, Gruclke EA (1999) Glass transition temperatures of polymers. In: Brandrup J, Immergut EH, Grulke EA (eds) Polymer handbook, 4th edn. Wiley, New York, pp 193-277 ((ISBN 0-471-16628-6))

Angelski DH (2014) Comparative analysis of methods for plastification of solid wood. J Int Sci Publ Mater Methods Technol 8:346-354 ((ISSN 1314-7269))

Anglès MN, Reguant J, Montané D, Ferrando F, Farriol X, Salvado J (1999) Binderless composites from pretreated residual softwood. J Appl Polym Sci 73:2485-2491

Anglès MN, Ferrando F, Farriol X, Salvadó J (2001) Suitability of steam exploded residual softwood for the production of binderless panels: effect of the pre-treatment severity and lignin addition. Biomass Bioenerg 21:211-224

Arruda LM, Del Menezzi CHS, de Andrade A (2015) Utilization of a thermomechanical process to enhance properties of hardwood used for flooring. Ciência da Madeira (Braz J Wood Sci) 6(3):223-231. https://doi.org/10.12953/2177-6830/rcm.v6n3p 223-231

Atack DWD (1972) On the characterization of pressurized refiner mechanical pulps. Sven Papperstidn 75:89-94

Aydin I, Colakoglu G, Hiziroglu S (2006) Surface characteristics of spruce veneers and shear strength of plywood as a function of log temperature in peeling process. Int J Solids Struct 43:6140-6147

Back EL (1987) The bonding mechanism in hardboard manufacture. Holzforschung 41:247-258

Back EL, Salmén L (1982) Glass transitions of wood components hold implications for molding and pulping processes. TAPPI J Tech Assoc Pulp Paper Ind 65(7):107-110

Baldwin RF (1975) Plywood manufacturing practices. Miller Freeman Publications Inc., San Fransisco, pp 62-78

Bánhegyi G (2005) Kristályos és amorf polimerek termikus vizsgálata differenciális pásztázó kalorimetriával (DSC)—A múanyagok tulajdonságai. (Differential Scanning Calorimetry Thermal Investigation of Crystalline and Amorphous Polymers - Properties of Plastics) Múanyagipari szemle 2005/1(Inspection of Plastics). (ISSN: 1785-7856)

Bardet S, Beauchêne J, Thibaut B (2003) Influence of basic density and temperature on mechanical properties perpendicular to grain of ten wood tropical species. Ann For Sci 60:49-59

Bariska M (1969) Plastifizierung des Holzes mit Ammoniak in Theorie und Praxis. (Plastification of wood with ammonia in theory and practice). Holz-Zentralblatt 5(84):1309-1311 (In German)

Bariska M, Schuerch C (1977) Wood softening and forming with ammonia. Wood technology: chemical aspects. pp 326-347. https ://doi.org/10.1021/bk-1977-0043.ch021

Baskaran M, Hashim R, Sulaiman O, Hiziroglu S, Sato M, Sugimoto $\mathrm{T}$ (2015) Optimization of press temperature and time for binderless particleboard manufactured from oil palm trunk biomass at different thickness levels. Mater Today Commun 3:87-95. https ://doi.org/10.1016/j.mtcomm.2015.04.005

Becker H, Noack D (1968) Studies on dynamic torsional viscoelasticity of wood. Wood Sci Technol 2(3):213-230. https://doi. org/10.1007/BF00350910

Bédard N, Poulain A (2000) Application de l'infrarouge au réchauffage de billes pour produits forestiers Donohue-essais de laboratoires (Application of infrared heating to bolts for forest products Donohue-experimental tests). Technical report, Hydro Quebec

Belleville B, Stevanovic T, Cloutier A, Pizzi A, Prado M, Erakovic S, Diouf PN, Royer M (2013) An investigation of thermochemical changes in Canadian hardwood species during wood welding. Eur J Wood Prod 71:245-257. https://doi.org/10.1007/s0010 7-013-0671-X

Belleville B, Koumba-Yoya G, Stevanovic T (2018) Effect of wood welding process on chemical constituents of Australian Eucalyptus. J Wood Chem Technol 39(1):43-56. https://doi. org/10.1080/02773813.2018.1494745

Berghel J, Frodeson S, Granström K, Renström R, Ståhl M, Nrodgren D, Tomani P (2013) The effects of kraft lignin additives on wood fuel pellet quality, energy use and shelf life. Fuel Process Technol 112:64-69. https://doi.org/10.1016/j.fuproc.2013.02.011

Boon JG, Hashim R, Sulaiman O, Hiziroglu S, Sugimoto T, Sato M (2013) Influence of processing parameters on some properties of oil palm trunk binderless particleboard. Eur J Wood Prod 71:583-589. https://doi.org/10.1007/s00107-013-0712-5

Bouajila J, Limare A, Joly C, Dole P (2005) Lignin plasticization to improve binderless fiberboard mechanical properties. Polym Eng Sci 45(6):809-816. https://doi.org/10.1002/pen.20342

Bouajila J, Dole P, Joly C, Limare A (2006) Some laws of a lignin plasticization. J Appl Polym Sci 102(2):1445-14451. https://doi. org/10.1002/app.24299

Bradfield J, Levi MP (1984) Effect of species and wood to bark ratio on pelleting of southern woods. For Prod J 34:61-63

Brebu M, Vasile C (2010) Thermal degradation of lignin - a review. Cellul Chem Technol 44(9):353-363

Calonego FW, Severo ETD, Cunha AR, Gaia DC (2010) Use of glass transition temperature for stabilization of board's cracks of Eucalyptus grandis. Anais da Academia Brasileira de Ciências (Ann Braz Acad Sci) 82(3):791-797

Castellano JM, Gómez M, Fernández M, Esteban LS, Carrasco JE (2015) Study on the effects of raw materials composition and palletization conditions on the quality and properties of pellets obtained from different woody and non woody biomasses. Fuel 139:629-636. https://doi.org/10.1016/j.fuel.2014.09.033

Chin OC, Siddiqui KM (2000) Characteristics of some biomass briquettes prepared under modest die pressures. Biomass Bioenerg $18: 223-228$

Chow S (1975) Bark board without synthetic resins. For Prod J 25(11):32-37

Chow S-Z, Pickles KJ (1971) Thermal softening and degradation of wood and bark. Wood Fiber Sci 3(3):166-178

Chung FH (1991) Unified theory and guidelines on adhesion. J Appl Polym Sci 42(5):1319-1331

Daoui A, Douzet J, Marchal R, Zerizer A (2007) Valorisation du bois de pin d'alep par de'roulage: optimisation de l'e'tuvage (Valorisation of Aleppo pine for peeling: optimisation of soaking). Bois et Fore^ts des Tropiques 294(4):51-64

Davidson RW, Baumgardt WG (1970) Plasticizing wood with ammonia-a progress report. For Prod J 20(3):19-25

Delmotte L, Ganne-Chedeville C, Leban JM, Pizzi A, Pichelin F (2008) CP-MAS ${ }^{13} \mathrm{C}$ NMR and FT-IR investigation of the degradation reactions of polymer constituents in wood welding. Polym Degrad Stab 93(2):406-412. https://doi.org/10.1016/j.polym degradstab.2007.11.020

Delmotte L, Mansouri HR, Omrani P, Pizzi A (2009) Influence of wood welding frequency on wood constituents chemical modifications. J Adhes Sci Technol 23(9):1271-1279. https://doi. org/10.1163/156856109X433991

Demirbaş A (1999) Physical properties of briquettes from waste paper and wheat straw mixtures. Energy Convers Manage 40(4):437445. https://doi.org/10.1016/S0196-8904(98)00111-3 
Demirbaş A, Şahin-Demirbaş A, Demirbaş AH (2004) Briquetting properties of biomass waste materials. Energy Sources 26(1):8391. https://doi.org/10.1080/00908310490251918

Donaldson LA (1985) Within- and between-tree variation in lignin concentration in the tracheid cell wall of Pinus radiata. NZ J Forest Sci 15(3):361-369

Donghua J, Afzal MT, Gongc M, Bedane AH (2010) Modeling of moisture diffusion and heat transfer during softening in wood densification. Int J Eng (IJE) 4(2):191-200 ((ISSN: 1985-2312))

Dundar T, As N, Korkut S, Unsal O (2008) The effect of boiling time on the surface roughness of rotary-cut veneers from oriental beech (Fagus orientalis L.). J Mater Process Technol 199(13):119-123. https://doi.org/10.1016/j.jmatprotec.2007.07.036

Dupleix A (2013) Feasibility of wood peeling assisted by infrared heating. Doctoral Dissertation 200/2013, Aalto University, Helsinki, Finland ISBN 978-952-60-5465-0 (pdf)

Dupleix A, Denaud L, Bléron L, Marchal R (2012) The effect of log heating temperature on the peeling process and veneer quality: beech, birch, and spruce case studies. Eur J Wood Prod 71(2):163-171. https://doi.org/10.1007/s00107-012-0656-1

Engelund ET, Thygesen LG, Svensson S, Hill C (2013) A critical discussion of the physics of wood-water interactions. Wood Sci Technol 47:141-161. https://doi.org/10.1007/s0022 6-012-0514-7

Fasina OO, Sokhansanj S (1995) Bulk thermal properties of alfalfa pellets. Canad J Eng 37(2):91-95

Felby C, Pedersen L, Nielsen B (1997) Enhanced auto-adhesion of wood fibres using phenol oxidases. Holzforschung 51:281-286

Felby C, Thygesen LG, Sanadi A, Barsberg S (2004) Native lignin for bonding of fiber boards - evaluation of bonding mechanisms in boards made from laccase-treated fibers of beech (Fagus sylvatica). Ind Crops Prod 20:181-189. https://doi.org/10.1016/j. indcrop.2004.04.020

Fergus BJ, Goring DAI (1970a) The location of guaiacyl and syringyl lignins in birch xylem tissue. Holzforschung 24(4):113-117. https://doi.org/10.1515/hfsg.1970.24.4.113

Fergus BJ, Goring DAI (1970b) The distribution of lignin in birch wood as determined by ultraviolet microscopy. Holzforschung 24(4):118-124. https://doi.org/10.1515/hfsg.1970.24.4.118

Fergus BJ, Procter AR, Scott JAN, Goring JAN (1969) The distribution of lignin in sprucewood as determined by ultraviolet microscopy. Wood Sci Technol 3(2):117-138. https://doi.org/10.1007/BF006 39636

Ferrandez-Villena M, Ferrandez-Garcia CE, Garcia-Ortuño T, Ferrandez-Garcia A, Ferrandez-Garcia MT (2020) The influence of processing and particle size on binderless particleboards made from Arundo donax L. rhizome. Polymers 12:696. https://doi. org/10.3390/polym12030696

Filbakk T, Jirjis R, Nurmi J, Høibø I (2011) The effect of bark content on quality parameters of Scots pine (Pinus sylvestris L.) pellets. Biomass Bioenerg 35:3342-3349. https://doi.org/10.1016/j. biombioe.2010.09.011

FPL (1943) Urea-plasticized wood (uralloy). USDA—Forest Products Laboratory, $6 \mathrm{pp}$

Frayssinhes R, Stefanowski S, Denaud L, Girardon S, Marcon B, Collet R (2019) Peeled veneer from douglas-fir: soaking temperature influence on the surface roughness. In: Proceedings of the 24th international wood machining seminar, Corvallis, August 25-28, 2019, pp 237-245

Fromm J, Rockel B, Lautner S, Windeisen E, Wanner G (2003) Lignin distribution in wood cell walls determined by TEM and backscattered SEM techniques. J Struct Biol 143:77-84

Furuta Y, Aizawa H, Yano H, Norimoto M (1997) Thermal-softening properties of water-swollen wood IV. The effects of chemical constituents of the cell wall on the thermal-softening properties of wood. Mokuzai Gakkaishi 43(9):725-730
Furuta Y, Imanishi H, Kohara M, Yokoyama M, Obata Y, Kanayama K (2000) Thermal-softening properties of water-swollen wood VII: the effects of lignin. Mokuzai Gakkaishi 46(2):132-136

Furuta Y, Kojiro K, Nakatani T, Nakajima M, Ishimaru Y (2008) The dynamic viscoelastic properties of wood in nonequilibrium states. J Soc Mater Sci Jpn 57(4):338-343

Furuta Y, Nakajima M, Nakanii E, Ohkoshi M (2010) The effect of lignin and hemicellulose on thermal-softening properties of water-swollen wood. Mokuzai Gakkaishi 56(3):132-138

Ganne-Chédeville C, Properzi M, Leban J-M, Pichelin F (2006) Parameters of wood welding: a study with infrared thermography. Holzforschung 60:434-438. https://doi.org/10.1515/HF.2006.068

Ganne-Chédeville C, Properzi M, Leban JM, Pizzi A, Pichelin F (2008) Wood welding: chemical and physical changes according to the welding time. J Adhes Sci Technol 22:761-773. https://doi. org/10.1163/156856108X295392

Gao Z, Wang X-M, Wan H, Brunette G (2011) Binderless panels made with black spruce bark. BioResources 6(4):3960-3972

Gašparík M, Barcík Š (2014) Effect of plasticizing by microwave heating on bending characteristics of beech wood. BioResources 9(3):4808-4820

Gašparík M, Gaff M (2013) Identification of factors influencing the maximum flexure of beech wood plasticized by microwave heating. Cellul Chem Technol 47(7-8):573-581

Gellerstedt G (2015) Softwood kraft lignin: raw material for the future. Ind Crops Prod 77:845-854. https://doi.org/10.1016/j.inder op.2015.09.040

Geng X, Zhang SY, Deng J (2006) Alkaline treatment of black spruce bark for the manufacture of binderless fiberboard. J Wood Chem Technol 26:313-324

Gfeller B, Lehmann M, Properzi M, Pichelin F, Zanetti M, Pizzi A, Delmotte L (2004) Interior wood joints by mechanical fusion welding of wood surfaces. For Prod J 54:72-79

Gierlinger N, Schwanninger M (2006) Chemical imaging of poplar wood cell walls by Confocal Raman Microscopy. Plant Physiol 140:1246-1254

Gilbert P, Ryu C, Sharifi V, Swithenbank J (2009) Effect of process parameters on pelletisation of herbaceous crops. Fuel 88:14911497. https://doi.org/10.1016/j.fuel.2009.03.015

Goring DAI (1963) Thermal softening of lignin, hemicellulose and cellulose. Pulp Paper Res Inst Canada 64:517-527

Goring DAI (1965) Thermal softening, adhesive properties and glass transitions in lignin, hemicellulose and cellulose. In Bolam F (ed) Consolidation of the Paper Web, Trans. of the IIIrd Fund. Res. Symp. Cambridge, pp 555-568, FRC, Manchester, 2018. https ://doi.org/10.15376/frc.1965.1.555.

Goring DAI (1971) Polymer properties of lignin and lignin derivatives. In: Sarkanen KV, Ludwig CH (eds) Lignins, occurrence, formation, structure, and reactions. Wiley, New York, pp 695-761

Granada E, González LML, Míguez JL, Moran J (2002) Fuel lignocellulosic briquettes, die design, and products study. Renew Energy 27:561-573

Halvarsson S, Edlund H, Norgen M (2009) Manufacture of non-resin wheat straw fibreboards. Ind Crops Prod 29:437-445. https://doi. org/10.1016/j.indcrop.2008.08.007

Hargitai H (2011) Polimerek fizikai, mechanikai, termikus tulajdonságai. (Physical, mechanical, thermal features of a polymer) (In Hungarian) Anyagismereti és Jármúgyártási Tanszék, Széchenyi István Egyetem

Hashim R, Said N, Lamaming J, Baskaran M, Sulaiman O, Sato M, Sugimoto $T$ (2011) Influence of press temperature on the properties of binderless particleboard made from oil palm trunk. Mater Des 32(5):2520-2525. https://doi.org/10.1016/j.matde s.2011.01.053

Hashim R, Nadhari WNAW, Sulaiman O, Sato M, Hiziroglu S, Kawamura F, Sugimoto T, Seng TG, Tanaka R (2012) Properties of 
binderless particleboard panels manufactured from oil palm biomass. BioResources 7(1):1352-1365

Hatakeyama H, Hatakeyama T (1998) Interaction between water and hydrophilic polymers. Thermochim Acta 308:3-22

Hatakeyama H, Hatakeyama T (2010) Thermal properties of isolated and in situ lignin. In: Heitner C, Dimmel D, Schmidt J (eds) Lignin and lignans: advances in chemistry. CRC Press, New York, pp 301-316

Hatakeyama H, Kubota K, Nakano J (1972) Thermal analysis of lignin by differential scanning calorimetry. Cellul Chem Technol 6:521-526

Hemmilä V, Trischler J, Sandberg D (2013) Lignin—an adhesive raw material of the future or waste of research energy. In: Brischke C, Meyer L (eds) In: Proc. 9th Meeting of the Northern European Network for Wood Science and Engineering (WSE) 2013. September 11-12, Hannover, pp 98-103

Hillis WE, Rozsa AN (1978) The softening temperature of wood. Holzforschung 32:68-73

Horváth B, Peralta P, Frazier C, Peszlen I (2011) Thermal softening of transgenic aspen. BioResources 6(2):2125-2134

Hubbe MA, Pizzi A, Zhang H, Halis R (2018) Critical links governing performance of self binding and natural binders for hot-pressed reconstituted lignocellulosic boards without added fromaldehyde: a review. BioResources 13(1):2049-2115

Husain Z, Zainac Z, Abdullah Z (2002) Briquetting of palm fibre and shell from the processing of palm nuts to palm oil. Biomass Bioenerg 22(6):505-509. https://doi.org/10.1016/S0961 -9534(02)00022-3

Hüttermann A, Kharazipour A, Schindel K, Fastenrath M, Noetzold S, Schroeter M, Hüttermann J, Hüttermann AH, von Kiedrowski G, Baumberger S, Lapierre C, Monties B (1998) Enzymatic reactions of activated lignin with nucleophiles as a basis for the design of compound materials with lignin. In: The 10 Int. Symp. on Wood and Pulping Chemistry, Vancouver, June 1998, A207-A209

Ibach RE (2010) Specialty treatments. In: Wood handbook: wood as an engineering material. USDA Forest Service, Forest Products Laboratory, General Technical Report FPL-GTR-190, pp $19.1-19.16$

Ichihara S, Komatsu A, Tsujita Y, Nose T, Hata T (1971) Thermodynamic studies on the glass transition and the glassy state of polymers I. Pressure dependence of the glass transition temperature and its relation to other thermodynamic properties of polystyrene. Polym J 2(4):530-534. https://doi.org/10.1295/ polymj.2.530

Irvine GM (1984) The glass transitions of lignin and hemicellulose and their measurement by differential thermal analysis. Tappi 67(5):118-121

Jonsson CYC (2009) Wooden fuel pellets. Raw material composition, mechanical strength, moisture content, particle size distribution and processing. Master's thesis, Luleå University of Technology, 083 (ISSN: 1653-0187)

Kaliyan N, Morey R (2006) Densification characteristics of corn stover and switchgrass. In: Presented at the ASABE Annual International Meeting, July 9-12, 2006, Portland, OR, ASABE Paper No. 066174, ASAE, St. Joseph

Kaliyan N, Morey RV (2009) Factors affecting strength and durability of densified biomass products. Biomass Bioenerg 33:337-359. https://doi.org/10.1016/j.biombioe.2008.08.005

Kaliyan N, Morey RV (2010) Natural binders and solid bridge type binding mechanisms in briquettes and pellets made from corn stover and switchgrass. Biores Technol 101:1082-1090. https:// doi.org/10.1016/j.biortech.2009.08.064

Kanazawa F, Pizzi A, Properzi M, Delmotte L, Pichelin F (2005) Parameters influencing wood-dowel welding by high-speed rotation. J Adhes Sci Technol 19(12):1025-1038. https://doi. org/10.1163/156856105774382444

Kawamoto H (2017) Lignin pyrolysis reactions. J Wood Sci 63:117132. https://doi.org/10.1007/s10086-016-1606-z

Kelley SS, Timothy GR, Glasser WG (1987) Relaxation behaviour of the amorphous components of wood. J Mater Sci 22(2):617-624

Kharazipour A, Bergmann K, Nonninger K, Hüttermann A (1998) Properties of fibre boards obtained by activation of the middle lamella lignin of wood fibres with peroxidase and $\mathrm{H} 2 \mathrm{O} 2$ before conventional pressing. J Adhes Sci Technol 12(10):1045-1053

Kong L, Zhao Z, He Z, Yi S (2017) Effects of steaming treatment on crystallinity and glass transition temperature of Eucalyptuses grandis $\times$ E. urophylla. Results Phys 7:914-919. https://doi. org/10.1016/j.rinp.2017.02.01

Koran Z (1979) Tensile properties of spruce under different conditions. Wood Fiber Sci 11(1):38-49

Kuokkanen M, Vilppo T, Kuokkanen T, Stoor T, Niinimäki J (2011) Additives in wood pellet production - a pilot-scale study of binding agent usage. BioResources 6(4):4331-4355

Kurokochi Y, Sato M (2015a) Properties of binderless board made from rice straw: the morphological effect of particles. Ind Crops Prod 69:55-59. https://doi.org/10.1016/j.indcrop.2015.01.044

Kurokochi Y, Sato M (2015b) Effect of surface structure, wax and silica on the properties of binderless board made from rice straw. Ind Crops Prod 77:949-953. https://doi.org/10.1016/j.inder op.2015.10.007

Kutnar A, Kamke FA (2012a) Compression of wood under saturated steam, superheated steam, and transient conditions at $150^{\circ} \mathrm{C}$, $160^{\circ} \mathrm{C}$, and $170^{\circ} \mathrm{C}$. Wood Sci Technol 46:73-88. https://doi. org/10.1007/s00226-010-0380-0

Kutnar A, Kamke FA (2012b) Influence of temperature and steam environment on set recovery of compressive deformation of wood. Wood Sci Technol 46:953-964. https://doi.org/10.1007/s0022 6-011-0456-5

Kutnar A, Šernek M (2007) Densification of wood. Zbornik gozdarstva in lesarstva 82:53-62

Kutnar A, Kamke FA, Šernek M (2009) Density profile and morphology of viscoelastic thermal compressed wood. Wood Sci Technol 43:57-68. https://doi.org/10.1007/s00226-008-0198-1

Laine C, Willberg-Keyriläinen P, Ropponen J, Liitiä T (2019) Lignin and lignin derivatives as components in biobased hot melt adhesives. J Appl Polym Sci 136:47983. https://doi.org/10.1002/ APP.47983

Lange PW (1954) The distribution of lignin in the cell wall of normal and reaction wood from spruce and a few hardwoods. Svensk Papperstidn 57:525-532

Leban JM, Pizzi A, Properzi M, Pichelin F, Gelhaye P, Rose C (2005) Wood welding: a challenging alternative to conventional wood gluing. Scand J For Res 20:534-538. https://doi. org/10.1080/02827580500432305

Lee S, Ahn BJ, Choi DH, Han G-S, Jeong H-S, Ahn SH, Yang I (2013) Effects of densification variables on the durability of wood pellets fabricated with Larix kaempferi C. and Liriodendron tulipifera $\mathrm{L}$. sawdust. Biomass Bioenerg 48:1-9

Lehmann B, Schröder H-W, Wollenberg R, Repke J-U (2012) Effect of miscanthus addition and different grinding processes on the quality of wood pellets. Biomass Bioenerg 44:150-159

Lehtikangas P (1999) Quality properties of fuel pellets from forest biomass. Licentiate Thesis, Department of Forest Management and Prodeucts, University of Uppsala, Report 4

Lehtikangas P (2001) Quality properties of pelletised sawdust, logging residues and bark. Biomass Bioenerg 20:351-360. https://doi. org/10.1016/S0961-9534(00)00092-1

Lenth CA (1999) Wood material behavior in severe environments. PhD Thesis, Virginia Polytechnic Institute and State University 
Lenth CA, Kamke FA (2001) Moisture dependent softening behavior of wood. Wood Fiber Sci 33(3):492-507

Li Y, Liu H (2000) High pressure densification of wood residues to form an upgraded fuel. Biomass Bioenerg 19(3):177-186. https ://doi.org/10.1016/S0961-9534(00)00026-X

Lisperguer J, Perez P, Urizar S (2009) Structure and thermal properties of lignins: characterization by infrared spectroscopy and differential scanning calorimetry. J Chil Chem Soc 54(4):460-463

Lu D, Tabil LG, Wang D, Wang G, Emami S (2014) Experimental trials to make wheat straw pellets with wood residue and binders. Biomass Bioenerg 69:287-296. https://doi.org/10.1016/j.biomb ioe.2014.07.029

Lui FHY, Kurokochi Y, Narita H, Saito Y, Sato M (2018) The effects of chemical components and particle size on the mechanical properties of binderless boards made from oak (Quercus spp.) logs degraded by shiitake fungi (Lentinula edodes). J Wood Sci 64:246-255. https://doi.org/10.1007/s10086-018-1695-y

Lutz JF (1960) Heating veneer bolts to improve quality of Douglas-fir plywood. USDA Forest Products Laboratory. Report No. 2182. $23 \mathrm{pp}$

Mani S, Tabil LG, Sokhansanj S (2004) Grinding performance and physical properties of wheat and barley straws, corn stover and switchgrass. Biomass Bioenerg 27(4):339-352. https://doi. org/10.1016/j.biombioe.2004.03.007

Mani S, Tabil LG, Sokhansanj S (2006a) Effect of compressive force, particle size and moisture content on mechanical properties of biomass pellets from grasses. Biomass Bioenerg 30(7):648-654. https://doi.org/10.1016/j.biombioe.2005.01.004

Mani S, Tabil LG, Sokhansanj S (2006b) Specific energy requirement for compacting corn stover. Biores Technol 97(12):1420-1426. https://doi.org/10.1016/j.biortech.2005.06.019

Mansouri HR, Omrani P, Pizzi A (2009) Improving the water resistance of linear vibration-welded wood joints. J Adhes Sci Technol 23(1):63-70. https://doi.org/10.1163/156856108X335595

Marchal R, Gaudilliere C, Collet R (2004) Technical feasibility of an embedded wood heating device on the slicer or the peeling lathe. In: 1st International symposium veneer processing and products proceedings, pp 29-44

Marchal R, Mothe F, Denaud L, Thibaut B, Bleron L (2009) Cutting forces in wood machining - basics and applications in industrial processes. A review COST Action E35 2004-2008: Wood machining-micromechanics and fracture. Holzforschung 63:157-167. https://doi.org/10.1515/hf.2009.014

Medved S (2010) Thermal modification of particleboard for dimensional stable product. In: Teischinger A, Barbu MC, Dunky M, Harper D, Jungmeier G, Militz H, Musso M, Petutschnigg A, Pizzi A, Wieland S, Young TM (eds) Processing technologies for the forest and biobased products industries. Proceedings of the 1 st international conference on processing technologies for the forest and biobased products industries, PTF BPI 2010 Salzburg University of Applied Sciences Kuchl/Austria, pp 183-185

Miki T, Sugimoto H, Kanayama K (2007) Thremoplastic bevaior of wood powder compacted materials. J Mater Sci 42:7913-7919. https://doi.org/10.1007/s10853-007-1723-6

Milawarni, Nurlaili, Sariadi, Amra S, Yassir (2019) Influence of press temperature on the properties of binderless particleboard. In: IOP Conf. series: materials science and engineering 536:012066. International conference on science and innovated engineering (I-COSINE) https://doi.org/10.1088/1757-899X/536/1/012066

Milotskyi R, Szabó L, Takahashi K, Bliard C (2019) Chemical modification of plasticized lignins using reactive extrusion. Front Chem 7:633. https://doi.org/10.3389/fchem.2019.00633

Miskolczi N (2012) Műanyagok kémiája és technológiája. (Chemist and Technology of Plastics), Pannon Egyetem (Pannon University)
Mobarak F, Fahmy Y, Augustin H (1982) Binderless lignocellulose composite from bagasse and mechanism of self-bonding. Holzforschung 36(3):131-136. https://doi.org/10.1515/ hfsg.1982.36.3.131

Morsing N, Hoffmeyer P (1998) Densification of wood: the influence of hygrothermal treatment on compression of beech perpendicular to gain. Kgs. Lyngby, Denmark: Technical University of Denmark (DTU). (BYG-Rapport; No. R-79).

Nakajima N, Furuta Y, Ishimaru Y (2008) Thermal-softening properties and cooling set of water-saturated bamboo within proportional limit. J Wood Sci 54:278-284. https://doi.org/10.1007/ s10086-008-0952-x

Nakajima M, Furuta Y, Ismiaru Y, Ohkoshi M (2009) The effect of lignin on the bending properties and fixation by cooling of wood. J Wood Sci 55:258-263. https://doi.org/10.1007/s1008 6-009-1019-3

Nasir M, Khali DP, Jawaid M, Tahir PM, Siakeng R, Asim M, Khan TA (2019) Recent development in binderless fiber-board fabrication from agricultural residues: a review. Constr Build Mater 211:502-516. https://doi.org/10.1016/j.conbuildmat.2019.03.279

Navi P, Sandberg D (2012) Thermo-hydro-mechanical processing of wood. EPFL Press, Lausanne

Ndiema CKW, Manga PN, Ruttoh CR (2002) Influence of die pressure on relaxation characteristics of briquetted biomass. Energy Convers Manage 43(16):2157-2161. https://doi.org/10.1016/ S0196-8904(01)00165-0

Nielsen NPK, Gardner DJ, Poulsen T, Felby C (2009) Importance of temperature, moisture content, and species for the conversion process of wood residues into pellets. Wood Fiber Sci 41(4):414-425

Nielsen NPK, Gardner DJ, Felby C (2010) Effect of extractives and storage on the pelletizing process of sawdust. Fuel 89:94-98

Nongman AF, Baharin A, Bakar AA (2016) The effect of banana leaves lamination on the mechanical properties of particle board panel. In: 5th international conference on recent advances in materials, minerals and environment (RAMM) \& 2nd international postgraduate conference on materials, mineral and polymer (MAMIP), vol 19. 4-6 August 2015. Procedia Chemistry pp 943-948. https://doi.org/10.1016/j.proch e.2016.03.139

Nyanhongo GO, Kudanga T, Prasetyo EN, Guebitz GM (2010) Mechanistic insights into laccasemediated functionalisation of lignocellulose material. Biotechnol Genet Eng 27:305-329

Obernberger I, Thek G (2004) Physical characterization and chemical composition of densified biomass fuels with regard to their combustion behavior. Biomass Bioenerg 27:653-669. https://doi. org/10.1016/j.biombioe.2003.07.006

Okuda N, Hori K, Sato M (2006a) Chemical changes of kenaf core binderless boards during hot pressing (I): influence of the pressing temperature condition. J Wood Sci 52(3):244-248. https:// doi.org/10.1007/s10086-005-0761-4

Okuda N, Hori K, Sato M (2006b) Chemical changes of kenaf core binderless boards during hot pressing (II): effects on the binderless board properties. J Wood Sci 52(3):249-254. https://doi. org/10.1007/s10086-005-0744-5

Olsson M (2006) Wheat straw and peat for fuel pellets-organic compounds from combustion. Biomass Bioenergy 30(6):555-564

Olsson AM, Salmén L (1992) Viscoelasticity of in situ lignin as affected by structure: softwood vs. hardwood. In: Glasser W (ed) Viscoelasticity of biomaterials. ACS Symposium Series No 489. American Chemical Society, Washington, pp 133-143

Olsson AM, Salmén L (1997) The effect of lignin composition on the viscoelastic properties of wood. Nord Pulp Pap Res J 12:140-144

Olsson AM, Salmén L (2003) Chapter 13-The softening behavior of hemicelluloses related to moisture. In: Gatenholm P, Tenkanen 
M (eds) Hemicelluloses: science and technology; ACS Symposium Series 864; American Chemical Society: Washington, DC

Olufemi B (2012) Yield and mechanical properties of veneer from Brachystegia nigerica. J For Res 23:295-298. https://doi. org/10.1007/s11676-012-0255-3

Omrani P, Masson E, Pizzi A, Mansouri HR (2008) Emission of gases and degradation volatiles from polymeric wood constituents in friction welding of wood dowels. Polym Degrad Stab 93(4):94799. https://doi.org/10.1016/j.polymdegradstab.2008.01.017

Omrani P, Mansouri HR, Pizzi A (2009) Influence of wood grain direction on linear welding. J Adhes Sci Technol 23(16):2047-2055. https://doi.org/10.1163/016942409X12526743387845

Östberg G, Salmen L, Terlecki J (1990) Softening temperature of moist wood by differential scanning calorimetry. Holzforshung 44(3):223-225

Oveisi-Fordiie E (2003) Durability of wood pellets. Master of Thesis, The Faculty of Graduate Studies (chemical and biological engineering), University of British Columbia

Peck EC (1957) Bending solid wood to form. Agriculture Handbook No. 125. USDA Forest Service

Pentoney RE (1966) Liquid ammonia-solvent combinations in wood plasticization. Properties of treated wood. Ind Eng Chem Prod Res Dev 5(2):105-110. https://doi.org/10.1021/i360018a003

Pereira L, Bastos C, Tzanov T, Cavaco PA, Guebizt GM (2005) Environmentally friendly bleaching of cotton using laccases. Environ Chem Lett 3(2):66-69

Petrič M (2013) Surface modification of wood: a critical review. Rev Adhes Adhes 1(2):216-247. https://doi.org/10.7569/ RAA.2013.097308

Pizzi A (2017) Chapter 6: Wood welding without adhesives. In: Davim JP, Aguilera A (eds) Wood composites: materials, manufacturing and engineering. Advanced Composites, vol 6. Walter de Gruyter GmbH \& Co KG, Berlin, pp 133-146 (ISBN $\mathbf{9 7 8 3 1 1 0 4 1 6 0 8 4 )}$

Pizzi A, Despres A, Mansouri HR, Leban JM, Rigolet S (2006) Wood joints by through-dowel rotation welding: microstructure, 13CNMR and water resistance. J Adhes Sci Technol 20(5):427436. https://doi.org/10.1163/156856106777144327

Placet V, Passard J, Perre P (2008) Viscoelastic properties of wood across the grain measured under water-saturated conditions up to $135^{\circ} \mathrm{C}$ : evidence of thermal degradation. J Mater Sci 43:3210-3217. https://doi.org/10.1007/s10853-008-2546-9

Properzi M, Leban JM, Pizzi A, Wieland S, Pichelin F, Lehmann M (2005) Influence of grain direction in vibrational wood welding. Holzforschung 59(1):23-27. https://doi.org/10.1515/ hf. 2005.004

Rautkari L, Laine K, Laflin N, Hughes M (2011) Surface modification of Scots pine: the effect of process parameters on the through thickness density profile. J Mater Sci 40:4780-4786

Rehkugler GE, Buchele WF (1969) Biomechanics of forage wafering. Trans ASAE 12(1):1-8

Relova I, Vignote S, León MA, Ambrosio Y (2009) Optimisation of the manufacturing variables of sawdust pellets from the bark of Pinus caribaea Morelet: particle size, moisture and pressure. Biomass Bioenerg 33:1351-1357. https://doi.org/10.1016/j. biombioe.2009.05.005

Rhén C, Gref R, Sjostrom M, Wiisterlund I (2005) Effects of raw material moisture content, densification pressure and temperature on some properties of Norway spruce pellets. Fuel Process Technol 87(1):11-16. https://doi.org/10.1016/j.fuproc.2005.03.003

Rhén C, Öhman M, Gref R, Wasterlund I (2007) Effect of raw material composition in woody biomass pellets on combustion characteristics. Biomass Bioenergy 31(1):66-72

Rohumaa A, Antikainen T, Hunt CG, Frihart CR, Hughes M (2016a) The influence of log soaking temperature on surface quality and integrity performance of birch (Betula pendula Roth) veneer.
Wood Sci Technol 50:463-474. https://doi.org/10.1007/s0022 6-016-0805-5

Rohumaa A, Hunt CG, Hughes M, Frihart CR, Kers J (2016b) Lathe check formation and their impact on evaluations of veneer-based panel bond quality. In: Proceedings of WCTE 2016-World conference on timber engineering, 8 pp (ISBN: 9783903039001)

Rohumaa A, Yamamoto A, Hunt CG, Frihart CR, Hughes M, Kers J (2016c) Effect of log soaking and the temperature of peeling on the properties of rotary-cut birch (Betula pendula Roth) veneer bonded with phenol-formaldehyde adhesive. BioResources 11(3):5829-5838

Rohumaa A, Hunt CG, Frihart CR, Kers J, Denaud L, Hughes M (2017) The impact of log heating on veneer quality and plywood performance. In: Proceedings, international scientific conference on hardwood processing. Lathi, pp 184-190. https://www.fpl.fs.fed. us/documnts/pdf2017/fpl_2017_rohumaa001.pdf

Rowell RM, McSweeny JD (2008) Heat treatments of wood fibers for self-bonding and stabilized fiberboards. Mol Cryst Liq Cryst 483(1):307-325

Rowell RM, Pettersen R, Han JS, Rowwel JS, Tshabalala MA (2005) Chapter 3: Cell wall chemistry. In: Rowell RM (ed) Handbook of wood chemistry and wood composites. CRC Press, Boca Raton, pp 35-74 ((ISBN: 9780849315886))

Runkel ROH, Wilke K (1951) Zur Kenntnis des thermoplastischen Verhaltens von Holz. Part 2. (On the thermoplastic behavior of wood). Holz Roh-Werkst 9:260-270 ((In German))

Ruponen J, Čermák P, Rhême M, Miettinen A, Rohumaa A, Rautkari L (2015) Influence of welding time on tensile-shear strength of linear friction welded birch (Betula pendula L.) wood. BioResources 10(2):3481-3461

Sadoh T (1981) Viscoelastic properties of wood in swelling systems. Wood Sci Technol 15:57-66

Saka S, Goring DAI (1985) Chapter 3: Localization of lignin in wood cell walls. In: Higuchi T (ed) (1985): Biosynthesis and biodegradation of wood components. Elsevier, Amsterdam ((ISBN: 978-0-12-347880-1))

Sakakibara A (1991) Chemistry of lignin-Chapter 4. In: Hon DN-S, Shiraishi N (eds) Wood and cellulosic chemistry. Marcel Dekker Inc., New York, pp 113-175 ((ISBN 0-8247-8304-2))

Sakata I, Senju R (1975) Thermoplastic behavior of lignin with various synthetic plasticizers. J Appl Polym Sci 19:2799-2810. https:// doi.org/10.1002/app.1975.070191015

Salmén L (1984) Viscoelastic properties of in situ lignin under watersaturated conditions. J Mater Sci 19(9):3090-3096

Samuelsson R, Larsson SH, Thyrel M, Lestander TA (2012) Moisture content and storage time influence the binding mechanisms in biofuel wood pellets. Appl Energy 99:109-115. https://doi. org/10.1016/j.apenergy.2012.05.004

Sandberg D, Johansson J (2005) A new method for bending solid wood-high frequency heating of beech. In: Bejó L (ed) Hardwood research and utilisation in Europe: new challenges. Proccedings of 1st Hardwood Conference, University of West Hungary Press, Sopron, pp 156-161

Sandberg D, Navi P (2007) Introduction to thermo-hydro-mechanical (THM) wood processing. Report No. 30 School of Technology and Design Växjö University (ISBN: 978-91-7636-561-8)

Sandberg D, Haller P, Navi P (2013) Thermo-hydro and thermohydromechanical wood processing: an opportunity for future environmentally friendly wood products. Wood Mat Sci Eng 8(1):64-88. https://doi.org/10.1080/17480272.2012.751935

Sarkanen KV (1975) Wood lignins. Chapter 6. In: Browning BL (ed) The chemistry of wood. Robert E Krieger Publishing Company, New York, pp 349-311 ((ISBN 0-88275-245-6))

Schaffer E (1973) Effect of pyrolytic temperatures on the longitudinal strength of dry Douglas-fir. J Test Eval 1(4):319-329. https://doi. org/10.1520/JTE10025J 
Schuerch C (1963) Plasticizing wood with liquid ammonia. Ind Eng Chem 55(10):39-39. https://doi.org/10.1021/ie50646a004

Scott JAN, Procter AR, Fergus BJ, Goring DAI (1969) The application of ultraviolet microscopy to the distribution of lignin in wood description and validity of the technique. Wood Sci Technol 3:73-92. https://doi.org/10.1007/BF00349985

Sehlstedt-Persson M (2005) Properties of solid wood: Responses to drying and heat treatment. Licentiate Thesis No. 70, Luleå University of Technology

Sen S, Sadeghifar H, Argyropoulos DS (2013) Kraft lignin chain extension chemistry via propargylation, oxidative coupling, and claisen rearrangement. Biomacromol 14(10):3399-3408. https ://doi.org/10.1021/bm4010172

Serrano C, Monedero E, Lapuerta M, Portero H (2011) Effect of moisture content, particle size and pine addition on quality parameters of barley straw pellets. Fuel Process Technol 92:699-706. https ://doi.org/10.1016/j.fuproc.2010.11.031

Shao S, Jin Z, Wen G, Iiyama K (2009) Thermo characteristics of steam-exploded bamboo (Phyllostachys pubescens) lignin. Wood Sci Technol 43(7-8):643-652

Shaw M (2008) Feedstock and process variables influencing biomass densification. MsC Thesis, Department of Agricultural and Bioresource Engineering, University of Saskatchewan

Skolmen RG (1967) Heating logs to relieve growth stresses. For Prod J 17:41-42

Smith IE, Probert SD, Stokes RE, Hansford RJ (1977) The briquetting of wheat straw. J Agric Eng Res 22(2):105-111. https://doi. org/10.1016/0021-8634(77)90054-3

Song X, Wang X, Kito K (2020) Effects of heating temperature on the properties of bio-board manufactured by using soybean straw. Materials 13(3):662. https://doi.org/10.3390/ma13030662

Šprdlík V, Brabec M, Mihailović S, Rademaher P (2016) Plasticity increase of beech veneer by steaming and gaseous ammonia treatment. Maderas Ciencia y tecnología 18(1):91-98. https:// doi.org/10.4067/S0718-221X2016005000009

Stamm B, Windeisen E, Natterer J, Wegener G (2005a) Thermal behaviour of polysaccharides in wood during friction welding. Holz Roh Werkst 63:388-389. https://doi.org/10.1007/s0010 7-005-0002-y

Stamm B, Natterer J, Navi P (2005b) Joining wood by friction welding. Holz Roh Werkst 63:313-320. https://doi.org/10.1007/s0010 7-005-0007-6

Stamm B, Windeisen E, Natterer J, Wegener G (2006) Chemical investigations on the thermal behaviour of wood during friction welding. Wood Sci Technol 40(7):615-627. https://doi.org/10.1007/ s00226-006-0097-2

Stelte W, Holm JK, Sanadi AR, Barsberg S, Ahrenfeldt J, Henriksen UB (2011a) A study of bonding and failure mechanisms in fuel pellets from different biomass resources. Biomass Bioenerg 35:910-918. https://doi.org/10.1016/j.biombioe.2010.11.003

Stelte W, Clemons C, Holm JK, Ahrenfeldt J, Henriksen UB, Sanadi AR (2011b) Thermal transitions of the amorphous polymers in wheat straw. Ind Crops Prod 34:1053-1056. https://doi. org/10.1016/j.indcrop.2011.03.014

Stelte W, Clemons C, Holm JK, Henriksen UB, Ahrenfeldt J, Sanadi AR (2012) Fuel pellets from Wheat straw: the effect of lignin glass transition and surface waxes on pelletizing properties. Bioenergy Resour 5:450-458. https://doi.org/10.1007/s1215 5-011-9169-8

Suchsland O, Woodson GE (1987) Fiberboard manufacturing practices in the United States. USDA Forest Service Agriculture Handbook No. 640

Suleman YH (2015) Softening and bending of black poplar (Рориlus nigra L.) wood with chemicals. J. Tikrit Univ For Agri Sci 15(4):15-20
Sun Y, Royer M, Diouf PN, Stevanovic T (2010) Chemical changes induced by high-speed rotation welding of wood-application to two Canadian hardwood species. J Adhes Sci Technol 24(810):383-1400. https://doi.org/10.1163/016942410X500990

Sutthoff B, Franz U, Hentschel H, Schaaf A (1996) Verfahren zum reibschweißartigen Fügen und Verbinden von Holz. (Method for friction-welded joining and bonding of wood), Patent specification DE 19620273 C2, Deutsches Patent- und Markenamt

Suzuki S, Shintani H, Park S-Y, Saito K, Laemsak N, Okuma M, Iiyama K (1998) Preparation of binderless boards from steam exploded pulps of oil palm (Elais guineensis Jaxq.) fronds and structural characteristics of lignin and wall polysacchrides in stema exploded pulps to be discussed for self-bindings. Holzforschung 52(4):417-426. https://doi.org/10.1515/hfsg.1998.52.4.417

Tabil LG, Sokhansanj S (1996a) Compression and compaction behavior of alfalfa grinds - part 2: compaction behavior. Powder Handl Process 8(2):117-122

Tabil LG, Sokhansanj S (1996b) Compression and compaction behavior of alfalfa grinds-part 1: compression behavior. Powder Handl Process 8(1):17-23

Tabil LG, Sokhansanj S (1997) Bulk properties of alfalfa grind in relation to its compaction characteristics. Appl Eng Agric 13(4):499505. https://doi.org/10.13031/2013.21618

Takahashi I, Sugimoto T, Takasu Y, Yamasaki M, Sasaki Y, Kikata Y (2010) Preparation of thermoplastic molding from steamed Japanese beech flour. Holzforschung. https://doi.org/10.1515/ hf. 2010.035

Tenorio C, Moya R, Valaert J (2016) Characterisation of pellets made from oil palm residues in Costa Rica. J Oil Palm Res 28:198210. https://doi.org/10.21894/jopr.2016.2802.08

Theerarattananoon K, Xu F, Wilson J, Staggenborg S, Mckinney L, Vadlani P, Pei Z, Wang D (2012) Effects of the pelleting conditions on chemical composition and sugar yield of corn stover, big bluestem, wheat straw, and sorghum stalk pellets. Bioprocess Biosyst Eng 35:615-623. https://doi.org/10.1007/s0044 9-011-0642-8

Thiebaud S, Borredon ME (1995) Solvent-free wood esterification with fatty acid chlorides. Biores Technol 52:169-173

Thomas M, van Vliet T, van der Poel AFB (1998) Physical quality of pelleted animal feed 3. Contribution of feedstuff components. Anim Feed Sci Technol 70:59-78. https://doi.org/10.1016/S0377 -8401(97)00072-2

Tshabalala MA, McSweeny JD, Rowell RM (2012) Heat treatment of wet wood fiber: a study of the effect of reaction conditions on the formation of furfurals. Wood Mat Sci Eng 7(4):202-208

Tu D, Su X, Zhang T, Fan W, Zhou Q (2014) Thermo-mechanical densification of Populus tomentosa var. tomentosa with low moisture content. BioResources 9(3):3846-3856

Tumuluru JS, Wright CT, Kenny KL, Hess JR (2010) A review on biomass densification technologies for energy application. Idaho National Laboratory, INL/EXT-10-18420

Uhmeier A, Morooka T, Norimoto M (1998) Influence of thermal softening and degradation on the radial compression behavior of wet spruce. Holzforshung 52(1):77-81

Urakami H, Nakato K (1966) The effect of temperature on torsional stress relaxation of wet Hinoki wood. J Jap Wood Res Soc $12: 118-123$

USDA (2010) Wood as engineering material Part 1: Chapter 19Bending and plasticizing wood. In USDA Wood Handbook, USDA, $\mathrm{p} 16$

Krevelen DW van (2009) Transition temperatures. In: Properties of polymers. pp 129-187. https://doi.org/10.1016/B978-0-08-05481 9-7.00006-6

van Dam JEG, van der Oever MJA, Teunissen W, Keijsers ERP, Peralta AG (2004) Process for production of high density/high 
performance binderless boards from whole coconut husk Part 1: lignin as intrinsic thermosetting binder resin. Ind Crops Prod 19:207-216. https://doi.org/10.1016/j.indcrop.2003.10.003

van Dam JEG, van der Oever MJA, Keijsers ERP, van der Putten JC, Anayron C, Josol F, Peralta AG (2006) Process for production of high density/high performance binderless boards from whole coconut husk. Part 2: coconut husk morphology, composition and properties. Ind Crops Prod 24:96-104. https://doi.org/10.1016/j. indcrop.2005.03.003

Vaziri M (2011) Water resistance of scots pine joints produced by linear friction welding. Doctoral Thesis, Division of Wood Science and Technology, Luleå University of Technology, LTU Skellefteå. 168 pp (ISBN 978-91-7439-205-0)

Vaziri M, Lindgren O, Pizzi A, Mansouri HR (2010) Moisture sensitivity of scots pine joints produced by linear frictional welding. J Adhes Sci Technol 24:8-10. https://doi.org/10.1163/01694 2410X501098

Vaziri M, Lindgren O, Pizzi A (2011) Influence of welding parameters and wood properties on the water absorption in Scots pine joints induced by linear welding. J Adhes Sci Technol 25(15):18391847. https://doi.org/10.1163/016942410X525731

Wamukonya L, Jenkins B (1995) Durability and relaxation of sawdust and wheatstraw briquettes as possible fuels for Kenya. Biomass Biomass 8(3):175-179. https://doi.org/10.1016/09619534(95)00016-Z

Wang B, Li DL, Chen TY, Qin ZY, Peng WX, Wen JL (2017) Understanding the mechanism of self-bonding of bamboo binderless boards: Investigating the structural changes of lignin macromolecules during molding pressing process. BioResources 12(1):514-532

Wattana W, Phetklung S, Jakaew W, Chumuthai S, Sriam P, Chanurai $\mathrm{N}$ (2017) Characterization of mixed biomass pellet made from oil palm and para-rubber tree residues. Energy Procedia 138:11281133. https://doi.org/10.1016/j.egypro.2017.10.218

Wellons J, Krahmer R (1973) Self bonding in bark composites. Wood Sci 6(2):112-122

Wert CA, Weller M, Caulfield D (1984) Dynamic loss properties of wood. J Appl Phys 56(9):2453-2458

Westermark U, Lidbrandt O, Eriksson I (1988) Lignin distribution in spruce (Picea abies) determined by mercurization with SEMEDXA technique. Wood Sci Technol 22:243-250

Whittaker C, Shield I (2017) Factors affecting wood, energy grass and straw pellet durability - a review. Renew Sustain Energy Rev 71:1-11. https://doi.org/10.1016/j.rser.2016.12.119

Widsten P, Kandelbauer A (2008) Adhesion improvement of lignocellulosic products by enzymatic pretreatment. Biotechnol Adv 26(4):379-386. https://doi.org/10.1016/j.biotechadv.2008.04.003

Widyorini R, Xu JY, Umemura K, Kawai S (2005) Manufacture and properties of binderless particleboard from bagasse I. Effects of raw material type, storage method, and manufacturing process. J Wood Sci 51(6):648-654

Widyorini R, Yudha AP, Prayitno TA (2011) Some of the properties of binderless particleboard manufactured from bamboo. Wood Res J 2(2):89-93

Wilfried P, Christa G, Michael G (2006) Pellet quality optimization. Systematic analysis of influencing factors along the productionprocess and microwave- and $\mathrm{H}_{2} \mathrm{O}_{2}$ - activation of the raw material. In: Proceedings of the 2nd World Conference on Pellets 2006, Jönköping, Sweden, pp 203-207

Windeisen E, Wegener G (2008) Behaviour of lignin during thermal treatments of wood. Ind Crops Prod 27:157-162. https://doi. org/10.1016/j.indcrop.2007.07.015

Wolcott MP (1989) Modeling viscoelastic cellular materials for the pressing of wood composites. PhD Thesis, Virginia Polytechnic Institute and State University
Wolcott MP, Shutler EL (2003) Temperature and moisture influence on compression recovery behavior of wood. Wood Fiber Sci 35(4):540-551

Wolcott MP, Kamke FA, Dillard DA (1990) Fundamentals of flakeboard manufacture: viscoelastic behavior of the wood component. Wood Fiber Sci 22(4):345-361

Xu J, Sugawara R, Widyorini R, Han G, Kawai S (2004) Manufacture and properties of low-density binderless particleboard from kenaf core. J Wood Sci 50:62-67. https://doi.org/10.1007/s1008 6-003-0522-1

Xu J, Widyorini R, Yamauchi H, Kawai S (2006) Development of binderless fiberboard from kenaf core. J Wood Sci 52:236-243. https ://doi.org/10.1007/s10086-005-0770-3

Xu Y, Wang B, Shen Y, Wu J, Feng L, Yu H (2017) Effect of softening treatment on cutting force during slicing the veneers of common fast-growing wood. BioResources 12(4):7205-7217

Yaman S, Şahan M, Haykiri-açtma H, Şeşen K, Kuçtiikbayrak S (2000) Production of fuel briquettes from olive refuse and paper mill waste. Fuel Process Technol 68(1):23-31. https://doi. org/10.1016/S0378-3820(00)00111-9

Yamauchi S, Iijima Y, Doi S (2005) Spectrochemical characterization by FT-Raman spectroscopy of wood heat-treated at low temperatures: Japanese larch and beech. J Wood Sci 51:498-506. https:// doi.org/10.1007/s10086-004-0691-6

Yelle DJ (2001) Bonding of wood fiber composites simulating natural wood cell adhesion using lignin activation systems. MsC Thesis, University of Minnesota

Zandersons J, Gravitis J, Zhurinsh A, Kokorevics A, Kallavus U, Suzuki CK (2004) Carbon materials obtained from self-binding sugar cane bagasse and deciduous wood residues plastics. Biomass Bioenerg 26:345-360

Zhanbin C (2003) Normal temperature briquetting technology for biomass with original moisture content. In: International conference on bioenergy utilization and environment protection 6th LAMNET Workshop, Dalian

Zhang D, Zhang A, Xue L (2015) A review of preparation of binderless fiberboards and its self-bonding mechanism. Wood Sci Technol 49:661-679. https://doi.org/10.1007/s00226-015-0728-6

Zhao L, Xia W, Tarverdi K, Song J (2013) Biocomposite boards from wheat straw without addition of bonding agent. Mater Sci Technol 30(5):603-610. https://doi.org/10.1179/1743284713y.00000 00459

Zhu X, Xue Y, Shen J, Thang S (2019) Withdrawal strength of welded dowel joints made of birch and larch wood. Wood Res 64(5):921-934

Zoller P (1982) A study of the pressure-volume-temperature relationships of four related amorphous polymers: polycarbonate, polyarylate, phenoxy, and polysulfone. J Polym Sci Polym Phys Edn 20(8):1453-1464. https://doi.org/10.1002/pol.1982.180200811

Zoller P, Kehl TA, Starkweather HW, Jones GA (1989) The equation of state and heat of fusion of poly(ether ether ketone). J Polym Sci Part B Polym Phys 27(5):993-1007. https://doi.org/10.1002/ polb.1989.090270503

Župčić I, Vlaović Z, Domljan D, Grbac I (2014) Influence of various wood species and cross-sections on strength of a dowel welding joint. Drvna Industrija 65(2):121-127. https://doi.org/10.5552/ drind.2014.1324

Publisher's Note Springer Nature remains neutral with regard to jurisdictional claims in published maps and institutional affiliations. 